Linköping Studies in Science and Technology

Dissertations, No. 1525

\title{
Plant lipid transfer proteins
}

\section{- Evolution, expression and function}

\author{
Monika Edstam
}

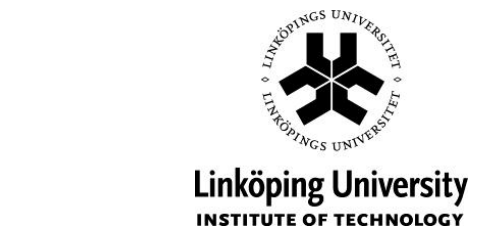

Department of Physics, Chemistry and Biology

Division of Biology

Linköping University

SE-581 83 Linköping, Sweden

Linköping 2013 
Linköping Studies in Science and Technology. Dissertations, No. 1525

Edstam, M. Plant lipid transfer proteins - Evolution, expression and function

ISBN 978-91-7519-578-0

ISSN 0345-7524

Copyright () Monika Edstam, unless otherwise stated.

Front cover: Picture of a seed coat from Arabidopsis, taken with a scanning electron microscope (by Monika Edstam).

Printed by LiU-Tryck

Linköping, Sweden 2013 


\section{Table of contents}

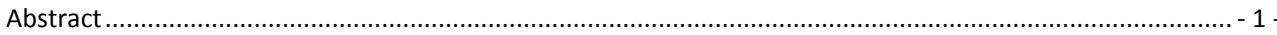

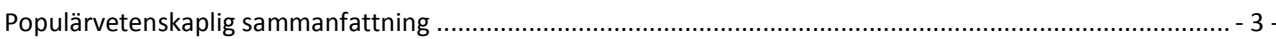

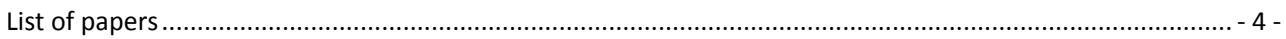

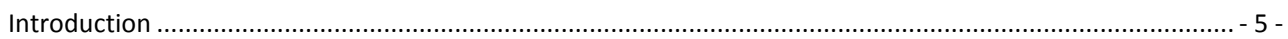

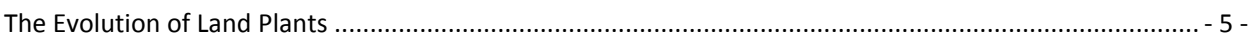

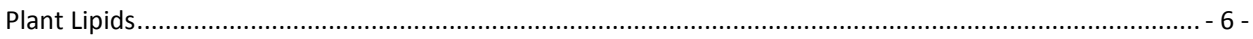

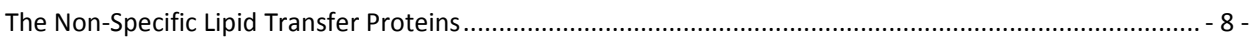

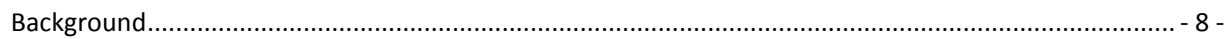

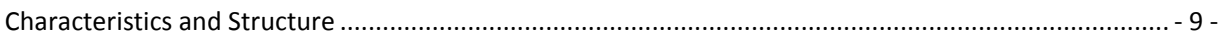

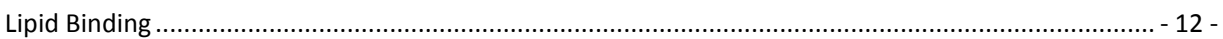

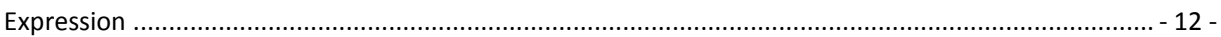

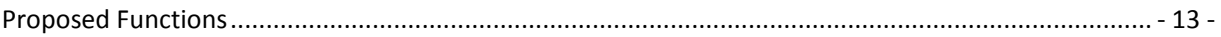

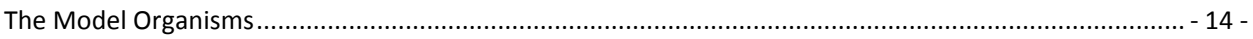

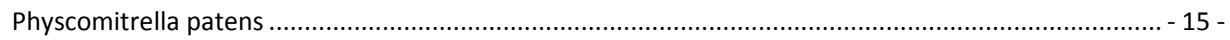

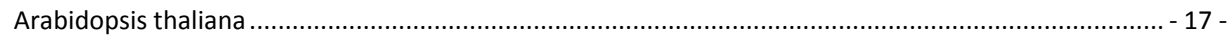

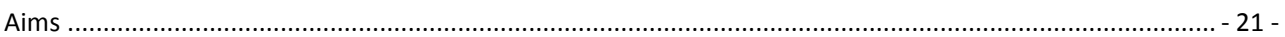

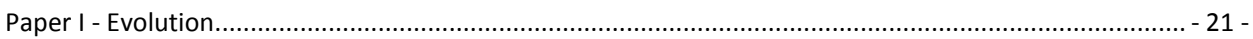

Paper II - Characterisation of LTPGs in Physcomitrella ..................................................................... 21 -

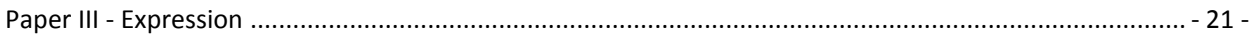

Paper IV - Knockout mutants in Arabidopsis ............................................................................... 22 -

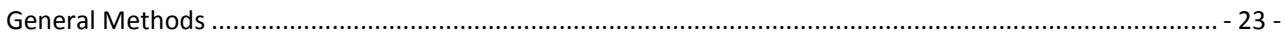

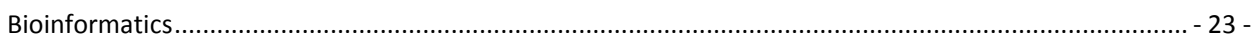

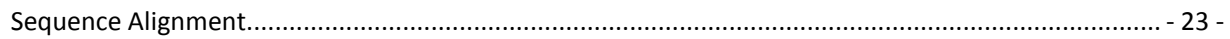

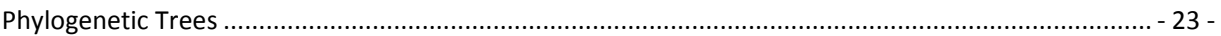

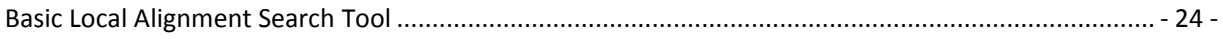

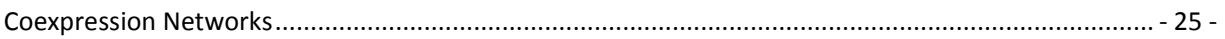

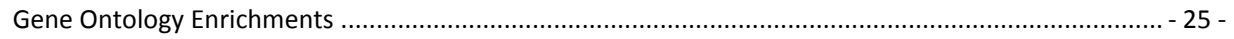

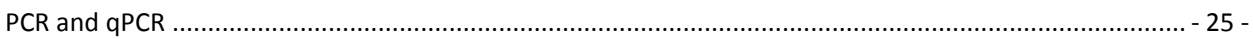

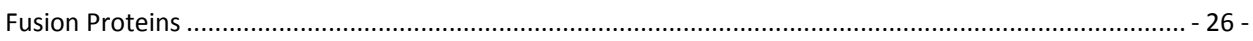

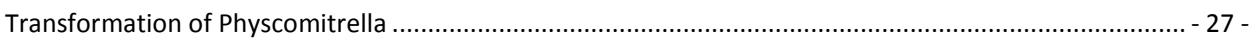

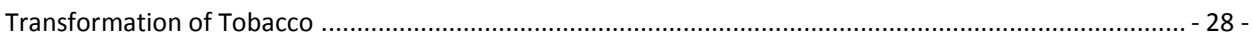

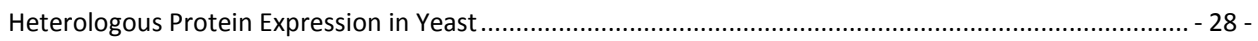

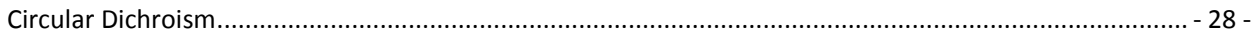

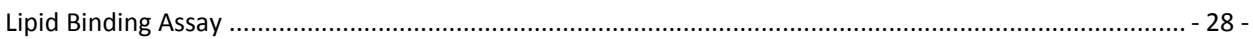

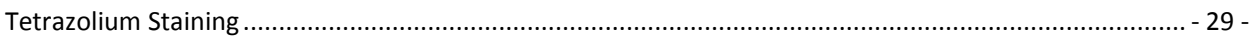

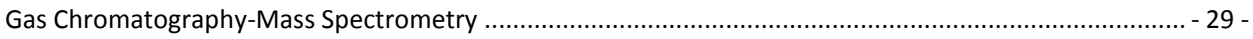

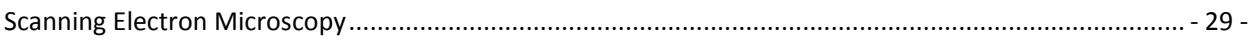

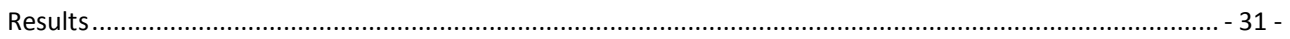

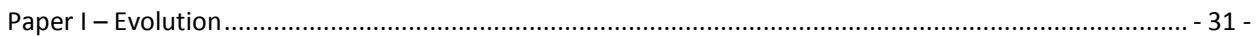

Paper II - Characterization of LTPGs in Physcomitrella ....................................................................... 32 -

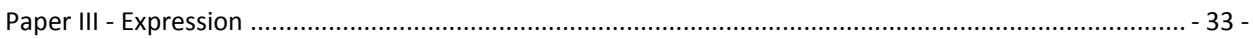

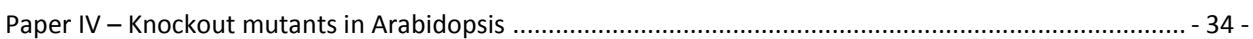

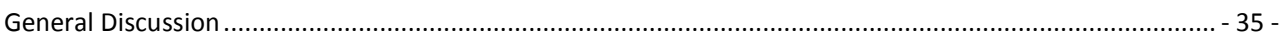

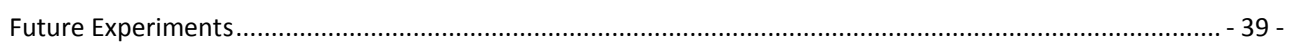

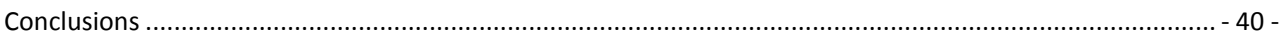

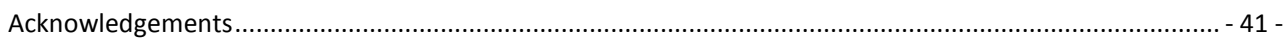

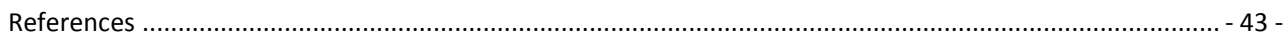





\section{Abstract}

The plant non-specific lipid transfer proteins (nsLTPs) are known for the ability to transfer different lipids in vitro, but their in vivo functions have not yet been elucidated. They seem to play a role in the defense against biotic and abiotic stresses; the gene expression of nsLTPs is

often upregulated when exposed to stresses. Further, two different nsLTPs have been shown to affect the lipid composition of the plant cuticle, a structure acting as a protective barrier. However, more evidence is needed to prove this hypothesis and to pinpoint their exact role in this process.

In this thesis I have shown that the nsLTPs are found in all land plants, but not in any of the studied algae. This supports a role in defense response, since protection against dehydration, radiation, pathogens and other stresses played a crucial role when plants adapted to a life on land. Characterization of the nsLTPs in early diverging land plant revealed that even though the amino acid similarity towards nsLTPs in flowering plants is not very high, the main properties of the proteins are still the same (Paper I). This includes the protein structure, which consists of $\alpha$-helices surrounding a lipid binding cavity, a conserved pattern of cysteine residues involved in disulphide bonds and a signal sequence directing the protein to the extracellular space. Further, the expression of nsLTPs in the moss Physcomitrella patens was shown to respond to stresses, and construction of an YFP-LTP fusion protein confirmed the localization to the periphery of the cell in planta (Paper II). Heterologous expressed Physcomitrella nsLTPs were also shown to have the ability to bind lipids and to be very heat stable, features previously only studied in nsLTPs from flowering plants. By examining the presence of a cuticle in Physcomitrella, a correlation between the nsLTPs' lipid binding ability and the lipid composition of the cuticle could be found, which further strengthens the involvement of nsLTPs in transfer of lipids for cuticle construction.

In the flowering plant Arabidopsis thaliana, I showed that several of the nsLTPs followed the same expression pattern when examining data from different tissues, stress treatments, hormones, chemical treatments and developmental stages, but also that four of the genes were undergoing alternative splicing resulting in different isoforms of the proteins (Paper III). Based on their expression patterns, the genes could be divided into three different coexpression networks. By examining other genes similarly expressed, each network could be designated to a putative function: Transfer of lipids for synthesis of the cuticle, suberin layer and sporopollenin, respectively. In Paper IV, these hypotheses were tested in vivo by examining knockout mutants of several nsLTPs in Arabidopsis. The involvement in 
sporopollenin deposition could be confirmed; two of the knockout lines showed collapsed pollen grains. Further, two other lines showed an increased seed coat permeability due to an altered lipid composition of the suberin layer. Together, the results support a role for nsLTPs in construction of the protecting barriers in all land plants. 


\section{Populärvetenskaplig sammanfattning}

Lipidtransporterande proteiner i växter spelar en viktig roll i flertalet sammanhang eftersom lipider är nödvändiga för vitt skilda ändamål, såsom uppbyggnad av cellmembran, signalering mellan cellerna och energiförvaring. Det finns därför också många olika typer av lipidtransportörer, där vissa har en väl klarlagd funktion medan andras fortfarande är en gåta. Non-specific lipidtransfer-proteiner (nsLTPer) har studerats mycket, men deras funktion är fortfarande mer eller mindre okänd. Man har bland annat kunnat påvisa en roll i växternas stressreaktioner och även i uppbyggnaden av skyddsbarriärer, men det finns ingen definitiv hypotes. Att det finns väldigt många nsLTPer i växterna och att olika studier ger resultat som pekar i olika riktningar försvårar arbetet med att bestämma funktionen en gång för alla. Genom att undersöka förekomsten av nsLTPer i tidigt divergerande landväxter, $\mathrm{t}$ ex levermossor och mossor, var hoppet att kunna förenkla framtida funktionsstudier. Det visade sig att nsLTPer förekommer i alla landväxter, men inte i några av de studerade algerna (Papper I). Resultatet indikerar att funktionen de har är något som blev nödvändigt först när växterna kom upp på land. Genom att studera nsLTPer i mossa (Physcomitrella patens) mer ingående kunde det konstateras att de har stora likheter med motsvarande proteiner från fröväxter, vad gäller bland annat proteinernas veckning, lipidbindande förmåga och stabilitet (Papper II). Det innebär att funktionsstudier av nsLTPer från Physcomitrella kan användas för att ge ledtrådar till funktionen även i fröväxter.

I den andra delen (Papper III och IV) ligger fokus istället på nsLTPer i den blommande fröväxten Arabidopsis thaliana. Genom att studera vilka nsLTP-gener som var uttryckta i vissa vävnader eller under vissa betingelser kunde de med liknande uttrycksmönster grupperas tillsammans med varandra, och sedan också med andra gener från hela Arabidopsis-genomet (Papper III). Genom att utnyttja det faktum att gener med liknande uttrycksmönster ofta är inblandade i samma biologiska processer framkom det ett förslag på funktion för varje gruppering. Alla innefattade uppbyggnad av olika försvarsbarriärer: Kutikulan på blad, suberinlagret i rötter och fröer samt sporopollenin som skyddar pollenkornet. Genom att studera mutanter, där en nsLTP saknades i varje mutant, kontrollerades riktigheten i de här hypoteserna (Papper IV). Bland mutanterna hittades ett par fall där pollenkornen sjunkit ihop och ytterligare ett par där fröernas skal var mindre skyddande än normalt, vilket tyder på att hypoteserna stämmer. 


\section{List of papers}

This thesis is based on the following four papers, referred to in text by their roman numerals.

Paper I Edstam, M.M., Viitanen, L., Salminen, T.A. \& Edqvist, J. 2011, "Evolutionary history of the non-specific lipid transfer proteins", Molecular plant, vol. 4, no. 6, pp. 947-964.

Paper II Edstam, M.M., Laurila, M., Höglund, A., Raman, A., Dahlström K.M., Salminen, T.A., Edqvist, J., Blomqvist, K. "Characterization of GPI-anchored lipid transfer proteins in Physcomitrella patens". Submitted to J. Exp. Bot.

Paper III Edstam, M.M., Blomqvist, K., Eklöf, A., Wennergren, U., Edqvist, J. "Coexpression patterns indicate that GPI-anchored non-specific lipid transfer proteins are involved in accumulation of cuticular wax, suberin and sporopollenin", Plant Mol Biol, DOI:10.1007/s11103-013-0113-5

Paper IV Edstam, M.M and Edqvist, J. "GPI-anchored lipid transfer proteins are involved in the development of seed coats and pollen in Arabidopsis". Manuscript. 


\section{Introduction}

\section{The Evolution of Land Plants}

The plant evolution probably began more than 1500 million years ago (Ma), when a cyanobacterium and a eukaryotic cell started an endosymbiotic relationship (Margulis, 1971; Yoon et al., 2003). The cyanobacterium was engulfed by the eukaryote and subsequently reduced to a chloroplast - the organelle involved in photosynthesis. The land colonization however began much later; the earliest evidence, in form of fossils, is dated to about $470 \mathrm{Ma}$ (Wellman et al., 2003). Estimations using molecular clock methods suggest the first land plants to have appeared about 900 to $500 \mathrm{Ma}$ (Zimmer et al., 2007; Clarke et al., 2011; Magallón et al., 2013). According to fossils, the morphology of the first land plants resembled most that of the extant liverworts (Wellman et al., 2003). They possessed cryptospores for reproduction and a cuticle for protection (Edwards, 2003; Wellman et al., 2003). The cuticle is a protective layer consisting mainly of lipids and is found on epidermal cells in the aerial parts of a plant. It was a very important structure in the transition from water to land, since it protects the plant from radiation, dehydration and pathogens (Jenks et al., 1994; Rozema et al., 1997). Several charophyte green algae have a cuticle-like fatty layer as protection against radiation, but no true cuticle (Cook and Graham, 1998). The charophyte green algae are thought to be the closest sister taxa to land plants (Karol, 2001). The spores of the first land plants, designated cryptospores, were airborne and had a protective layer of sporopollenin (Kenrick and Crane, 1997a). Sporopollenin is a lipid polymer highly stable to degradation (Brooks and Shaw, 1968).

The first evidence of tubes, indicating a vascular system, is fossils from about $415 \mathrm{Ma}$ (Edwards et al., 1992). A vascular system made it possible for the plants to grow larger and these plants soon became dominating. Today, the only non-vascular land plant lineages are liverworts, hornworts and mosses. The first indications of roots originate from the early Devonian time (419-393 Ma) and resemble most the rhizoids found in extant mosses and liverworts (Kenrick and Crane, 1997b). The roots have two main functions for the plant: Anchoring and uptake of water and nutrients. As the plant grew bigger, thanks to the vascular system, a larger root became necessary and evolved during the middle Devonian time (393$382 \mathrm{Ma}$ ) (Kenrick and Crane, 1997b). The leaf evolved later, probably about $360 \mathrm{Ma}$ (Kenrick and Crane, 1997b). The leaves provided the plants with an increased area exposed to sunlight, and thus a higher rate of photosynthesis. There are two different types of leafs; microphylls 
and megaphylls, which are thought to have evolved separately (Kenrick and Crane, 1997b). Microphylls are leafs with one central vein while the megaphylls (or true leafs) have a complex vascular system. The microphylls probably evolved earlier but are now only found in the lycophytes, while the megaphylls are found in all other vascular plants.

The first plants reproducing with seeds instead of spores were gymnosperms, which seem to have evolved about $365 \mathrm{Ma}$ (Fairon-Demaret, 1997). The first angiosperms (flowering plants) arose much later, probably during the late Jurassic (161-145 Ma) (Sun et al., 1998). Today the angiosperms are dominating the world flora with more than 200000 species (Scotland and Wortley, 2003).

\section{Plant Lipids}

Lipids are small hydrophobic or amphiphilic molecules with a backbone of carbons. There are eight different classes of lipids; fatty acids, sterols, prenols, sphingolipids, glycerolipids, glycerophospholipids, saccharolipids and polyketides (Fahy et al., 2005). Fatty acids consist of a hydrophilic carboxyl group with a hydrophobic tail, with different chain length (Fig. 1). Fatty acids can be saturated or unsaturated and have different functional groups in addition to the carboxyl group. Further, they are often part of more complex lipids, including wax esters and glycerolipids. The sterols are based on a completely different structure, where the core is consisting of four rings, and are often functioning as hormones (Fig. 1). Sterols also play an important role in membranes, where they affect the fluidity. The prenol lipids are all synthesized from different number of isoprene units, and includes carotenoids and other antioxidants (Demmig-Adams and Adams, 2002; Kuzuyama and Seto, 2003). Sphingolipids always have a sphingoid base, consisting of the amino acid serine together with a fatty acid, but many different functional groups and side chains occur in this complex lipid class (Lynch and Dunn, 2004). Sphingolipids are constituents of membranes, but also involved in signaling. The glycerolipids includes all lipids containing a glycerol molecule. The most well-known are the triacylglycerols, consisting of a glycerol with three fatty acid chains, which are used for energy storage in the cells (Murphy, 1993). Glycerophospholipids, or just phospholipids, have a polar phosphate head group with two hydrophobic tails, attached via a glycerol molecule. Phospholipids are the main constituents of cell membranes. Saccharolipids are compound with fatty acids linked directly to a sugar backbone. The polyketides are structually diverse but are always derived from condensation of ketoacyl subunits. These molecules often have antibiotic effects (Robinson, 1991). 
In plants, there are three main functions for lipids - energy storage, signaling and protection. In addition to this, amphiphilic lipids are the main constituents of membranes in the plant cell, as well as in every other eukaryotic organism. Lipids are also important for photosynthesis, both as constituents of the thylakoid membranes and by interacting with the photosynthetic protein complexes Photosystem I and II (Reviewed by Jones, 2007).

A

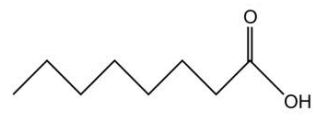

B

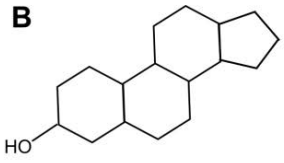

Figure 1. Two lipids, belonging to different classes. (A) Fatty acid (Octanoic acid) (B) Sterol.

The energy storage in plants mainly occurs in the form of starch, lipids or proteins, and which form is preferred varies between different species and tissues. Lipids are most often used for storage in the seeds, while starch is common in roots and other underground tissues. Lipids as energy storage usually mean triacylglycerols, which are stored in oil bodies inside the cell (Murphy, 1993). However, waxes are sometimes used for this purpose, for example in jojoba seeds (Moreau and Huang, 1977). Further, lipids play an important role in plant signaling; many hormones are lipids, e. g. the phytosterols (derived from sterol) and the jasmonates. These hormones are involved in different pathways, including defense response, programmed cell death and germination (Reinbothe et al., 2009; Wang et al., 2012; Zalewski et al., 2012). Several lipids function as important second messengers in intracellular signaling, for example phosphatidic acid in the Phospholipase $\mathrm{C}$ and $\mathrm{D}$ signaling pathways and fatty acids in auxin signaling (Paul et al., 1998; Munnik, 2001). Except for the involvement of lipids in defense signaling, more direct protective roles are also present; lipids are the main constituents in many defense barriers in plants, including the cuticle and wax layers of leafs, fruit and flowers (Schreiber, 2010). Due to the hydrophobic nature of lipid molecules, they are not able to move freely in the hydrophilic protoplasm or through the cell wall. Instead they need to be transported by other molecules. Some of these transporters have been identified, for example the protein Trigalactosyldiacylglycerol 4, which transfers lipids from the endoplasmic reticulum to the plastids (Xu et al., 2008). However, there are still several key transporters that have not been found. This includes the transporter protein of lipid molecules to the cuticle through the cell wall. 


\section{The Non-Specific Lipid Transfer Proteins}

\section{Background}

The plant non-specific lipid transfer proteins (nsLTPs) are extensively studied, but yet their in vivo function is not elucidated. The nsLTPs were first discovered in potato tubers almost 40 years ago, although they were then known as phospholipid transfer proteins and thought to be involved in intracellular lipid trafficking (Kader, 1975). The ability to transfer phospholipids between membranes was shown in vitro in several studies and this hypothesis was widely accepted for many years, even after some nsLTPs were shown to be extracellular (Kader et al., 1984; Bernhard and Somerville, 1989; Arondel and Kader 1990; Sterk et al., 1991; Thoma et al., 1993). The name phospholipid transfer protein was exchanged to lipid transfer protein, and later non-specific lipid transfer protein, when the proteins were shown to be able to bind and transfer different lipids, including fatty acids and fatty acyl-Coenzyme A (Arondel et al., 1990; Tsuboi et al., 1992). Similarly as the name, the hypotheses about the nsLTPs' functions have come and gone during time. Outplayed is their suggested role in intracellular lipid trafficking, replaced by theories about pathogen defense, cuticle formation and pollen tube adhesion, among others (Park et al., 2000; Maldonado et al., 2002; Cameron et al., 2006). The nsLTPs belong to the plant specific prolamin super family, which is characterized by conserved cysteine residues, low molecular mass and a high content of $\alpha$-helices (Kreis et al., 1985; Shewry et al., 2002). Except for the nsLTPs, the prolamin superfamily consists of the $\alpha$ amylase inhibitors, the prolamins, the $2 \mathrm{~S}$ albumins, the indolines and the hybrid proline-rich proteins (Radauer and Breiteneder, 2007). Many of the proteins in this superfamily, including the nsLTPs, are known to cause food allergy in human (Toriyama et al., 1998; Pastorello et al., 1999; Asero et al., 2000). In the Mediterranean area it is common with severe allergy to food derived from the rosaceae family (including almonds, apples and peach) and nsLTPs have been shown to be the allergens responsible for this (Sanchez-Monge et al., 1999). Later nsLTPs have also been identified as allergens in e.g. oranges, tomato, hazelnut, olive tree pollen and cabbage (Tejera et al., 1999; Pastorello et al., 2002; Ahrazem et al., 2005; Le et al., 2006; Palacin et al., 2006). Due to the similarity in structure between nsLTPs from different plants, there is a high rate of cross-reactivity (Egger et al., 2010).

The nsLTPs have been found in many different land plants, including Arabidopsis, rice, wheat, pine, peach and corn (Pasquato et al., 2006; Boutrot et al., 2008; Jang et al., 2008;

Kirubakaran et al., 2008; Kovaleva et al., 2009). The protein family is very large, with more than 150 members in wheat, 49 in Arabidopsis and 52 in rice (Boutrot et al., 2008). Lipid 
transfer proteins are found not only in plants, but in mammals as well (Bloj and Zilversmit, 1981; Ossendorp et al., 1992). However, these proteins are not structurally or sequentially related to the lipid transfer proteins found in plants (Wirtz, 1991).

The proteins have traditionally been divided into two different types, according to size. The LTPs belonging to Type 1 was first discovered, and they have a size about $9 \mathrm{kDa}$ (Arondel and Kader, 1990). Several years later the smaller (usually $7 \mathrm{kDa}$ ) Type 2 was found in barley and wheat (Castagnaro and Garcia-Olmedo, 1994; Kalla et al., 1994). The two original types have persisted through time, but more recently several additional types have been found (Boutrot et al., 2008; Lascombe et al., 2008). It is not yet clear whether the different types differ in function or lipid preferences.

\section{Characteristics and Structure}

A typical nsLTP consists of approximately 100 amino acids, of which 20-30 constitute the Nterminal signal peptide that directs the protein to the secretory pathway (Fig. 2) (Tchang et al., 1988; Bernhard et al., 1991). Accordingly, several nsLTPs have been found in the cell wall, but some have been reported from intracellular organelles as well (Tsuboi et al., 1992; Thoma et al., 1993; Nishimura et al., 2008; Pagnussat et al., 2012). Among the amino acids in the mature protein there are always eight cysteine residues conserved in a specific pattern, known as an eight cysteine motif (8CM) (José-Estanyol et al., 2004). The 8CM in nsLTPs have the general form $C-X_{n}-C-X_{n}-C C-X_{n}-C X C-X_{n}-C-X_{n}-C$, where $X$ is any amino acid and $n$ any number of amino acids (Fig. 2). The eight cysteines are involved in four intramolecular disulphide bridges that stabilize the tertiary structure of the protein (Shin et al., 1995; Lascombe et al., 2008). Thus, the nsLTPs are very stable to heat and different denaturing agents (Lindorff-Larsen and Winther, 2001). Further, the nsLTP proteins are soluble and usually have a high pI due to many charged amino acids (Liu et al., 2002; Castro et al., 2003). There are few conserved amino acids except for the cysteines, especially when comparing proteins from different types (Boutrot et al., 2007). Another frequently occurring feature among the genes encoding nsLTPs is an intron located after the last cysteine in the 8CM (Ma et al., 1997; Trevino and OConnell, 1998; Boutrot et al., 2005).

\section{MANSSAVLVLLVVTLLVATLLKETQAACGSSYDLAACLPAAESDIQPSAQCCTQLSSYLA TDTPEECLCQTAYSPFFQSGADIQFAIKIPQKCNLSYRAGIQCNGNTIPGGQ}

Figure 2. The amino acid sequence of a typical nsLTP (LTPld from Physcomitrella patens). The part with dark grey background is the N-terminal signal sequence directing the protein to the secretory pathway. The eight cysteines are shown in pale grey. The arrow indicates the position of the intron in the corresponding gene. 
The members of one type of nsLTPs, namely Type G, possess a C-terminal signal sequence in addition to the N-terminal one (Borner et al., 2002; Boutrot et al., 2008; DeBono et al., 2009; Lee et al., 2009). This signal sequence leads to a posttranslational modification where a glycosylphosphatidylinositol(GPI)-anchor is added to the C-terminal end of the protein. The GPI-anchor attaches the protein on the extracellular side of the plasma membrane, by integration of the phosphatidylinositol into the membrane (Fig. 3) (Ikezawa, 2002; Paulick and Bertozzi, 2008). The protein can be released from the anchor through cleavage by phospholipases (Paulick and Bertozzi, 2008; Müller et al., 2012). Further, many GPIanchored proteins are occasionally taken into the cell by endocytosis (Mayor and Riezman, 2002; Sabharanjak et al., 2002; Lakhan and Sabharanjak, 2009). GPI-anchors are not unique for nsLTPs, but found on proteins from many different families in most eukaryotes (Ferguson et al., 2009). One example is the human protein thymocyte differentiation antigen-1, which is modulating signals for e.g. apoptosis, cellular adhesion and cell proliferation (Rege and Hagood, 2006). Further, GPI-anchors also play an important role in prion diseases; prion proteins lacking the GPI-anchor that usually attach them to the cell surface of the host's cells are less malign than the GPI-anchored ones (Chesebro et al., 2005).

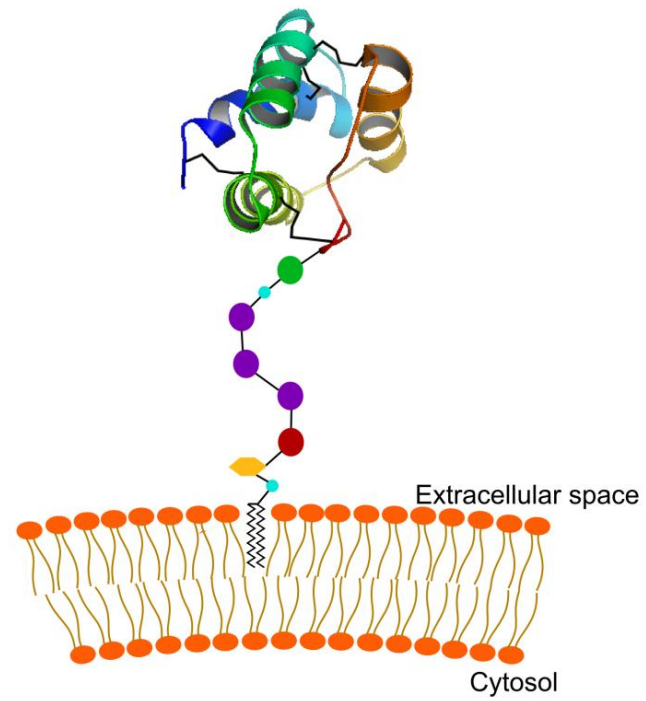

Figure 3. An nsLTP attached to the plasma membrane through a GPI-anchor. The anchor consists of one ethanolamine (green), three mannose molecules (purple), one glucosamine (red) and one inositol (yellow). There is a phosphate molecule (cyan) between the ethanolamine and the mannoses, and between the inositol and the lipid tails. The inositol with the phosphate and the lipid tails together constitutes the phosphatidylinositol. 
The crystal structure has been determined for several nsLTPs, among them one from peach, one from rice, one from Arabidopsis and one from maize (Gomar et al., 1996; Poznanski et al., 1999; Pasquato et al., 2006; Lascombe et al., 2008). The structural studies have determined that the folding of nsLTP proteins occurs in two different ways, namely the Type 1 and the Type 2 fold. In the Type 1 fold, which is only found in the proteins belonging to Type 1 , the disulphide bridges are formed by the cysteine residues 1-6, 2-3, 4-7 and 5-8 (Gincel et al., 1994; Shin et al., 1995). In the Type 2 fold, which is present in all types but Type 1, the fifth and the sixth cysteines have switched partners and the bridges are formed between the cysteine residues 1-5, 2-3, 4-7 and 6-8 instead (Samuel et al., 2002). However, both variants give rise to similar tertiary structures with four or five $\alpha$-helices and a central cavity (Fig. 4). The interior of the cavity is lined by hydrophobic amino acids, making it suitable for lipid binding. In Type 1 the cavity is tunnel-like, with two entrances of different size, while there is only one opening in nsLTPs with the Type 2 fold (Shin et al., 1995; Lee et al., 1998; Samuel et al., 2002). The cavity of Type 2 folded nsLTPs is also more flexible than that of Type 1 , resulting in lower lipid specificity. For example, nsLTPs with the Type 1 fold are not able to bind sterols, in opposite to those with the Type 2 fold (Samuel et al., 2002).

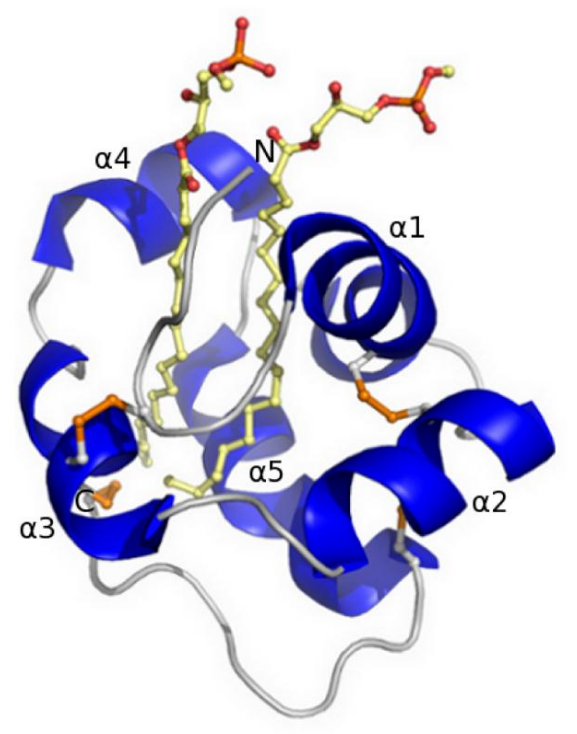

Figure 4. The crystal structure of the nsLTPd DIR1 from Arabidopsis, with the Type 2 fold, in complex with two lysophosphatidyl choline molecules (in yellow). The helices of the protein are shown in blue and the disulphide bonds in orange. This is a part of Figure 5 in Paper I. 


\section{Lipid Binding}

The nsLTPs have the ability to transfer lipids between monolayers in vitro. However, for most nsLTPs the lipid binding ability has not been examined, but they are considered as nsLTPs due to sequence similarity to known sequences. In cases where the lipid binding ability has been studied, most of the nsLTPs have been shown to be non-specific in terms of lipid binding ability. Consequently, they are able to bind various different lipids, including phospholipids, fatty acids and acyl-CoA (Ostergaard et al., 1993; Shin et al., 1995). However, some lipids seem to be bound more efficiently than others. Using fluorescence labeled fatty acids, an nsLTP from maize showed highest affinity for those with chain lengths of 16-19 carbons, while hydroxyl groups or polyunsaturations reduced the affinity (Zachowski et al., 1998). Similar results are reported for a wheat nsLTP, where the method steady-state tyrosine fluorescence was used; the affinity is higher with chain lengths of 14-18 carbons compared to shorter chains and reduced by hydroxyl groups, but not unsaturations (Douliez et al., 2000). Further, an nsLTP from ginkgo has been shown to have a low affinity for saturated and transunsaturated fatty acids, but high when they were cis-unsaturated (Sawano et al., 2008). There are also some studies showing that the nsLTPs are able to bind two lipid molecules at the same time (Sodano et al., 1997; Charvolin et al., 1999; Lascombe et al., 2008). Further, the volume of the tunnel has been shown to increase when a lipid is bound, wherefore it is impossible to predict the binding ability of an nsLTP by looking at the size of the tunnel (Tassin-Moindrot et al., 2000; Han et al., 2001). It has also been shown that conformational changes, where some amino acids are reoriented, occur within the protein upon lipid binding to better accommodate hydrophobic or hydrophilic side chains of the lipids (Tassin-Moindrot et al., 2000). There is no clear difference in lipid preferences between nsLTPs from the different types, except for some bulky lipids that are too large for proteins with the more rigid Type 1 fold (Samuel et al., 2002; Cheng et al., 2004).

\section{Expression}

The typical nsLTP is highly expressed in epidermal tissues of the aerial part of the plant, including leaves, shoot meristems and flower (Gausing, 1994; Kotilainen et al., 1994; Thoma et al., 1994). Others are found in almost all tissues, but with different expression patterns during different stages of plant development (Sossountzov et al., 1991; Canevascini et al., 1996; Clark and Bohnert, 1999). For example, NtLTP1 from tobacco is mainly expressed in epidermis in adult tissue, but in young tissues the expression was much broader and found in roots and hypocotyl as well (Canevascini et al., 1996). Some nsLTPs are however specifically 
expressed in one or a few tissues, including root, anther, trichomes or seed (Blilou et al., 2000; Chen et al., 2011; Choi et al., 2012; Kovalchuk et al., 2012). In many cases the expression of the nsLTPs are upregulated by different biotic and abiotic stresses, including abscisic acid and salicylic acid in strawberry and bacterial infection in barley (Yubero-Serrano et al., 2003; Petti et al., 2010). This have been shown for several additional nsLTPs from different species, including mungbean, bromegrass, sunflower, rice and Arabidopsis (Vignols et al., 1997; Liu and Lin, 2003; Wu et al., 2004; Gonorazky et al., 2005; Brotman et al., 2012). Further, nsLTPs are often found to be differentially expressed in various mutants. One example is the double mutant of the RNA binding proteins TSN1 and TSN2 (Tudor-SN) in Arabidopsis, where six nsLTPs are downregulated during normal conditions, salt stress or both (dit Frey et al., 2010).

\section{Proposed Functions}

As mentioned earlier, there are many different hypotheses regarding the functions of nsLTPs. One of the more well-established is a role in transport of lipids to the cuticle, through the cell wall (Pyee et al., 1991; Sterk et al., 1991; Kunst and Samuels, 2003). This has indirectly been shown for some Type G nsLTPs in Arabidopsis, where knockout/knockdown mutants have a lower wax load in the stem compared to wild-type plants (Debono et al., 2009; Lee et al., 2009; Kim et al., 2012). Their exact role in this lipid deposition, or the mechanism behind it, is however not clarified.

Another nsLTP from Arabidopsis, named DIR1, have been shown to be essential for long distance signaling in systemic acquired resistance (SAR) in Arabidopsis (Maldonado et al., 2002). The knockout mutant of DIR1 was shown to lack the ability to develop SAR in response to infection by Pseudomonas syringae and Peronospora parasitica. In agreement to this, several nsLTPs have been shown to be upregulated when exposed to biotic stresses, including the bacterium Xanthomonas campestris in cauliflower, the fungus Puccinia melanocephala in sugarcane and a tobacco mosaic virus in pepper (Park et al., 2002; Jiang et al., 2011; Oloriz et al., 2012). Further, some nsLTP have been shown to have antibiotic, antiviral or antifungal properties in vitro, supporting a role in defense against microorganisms (Molina et al., 1993; Nielsen et al., 1996; Wang et al., 2004; Ooi et al., 2008). This is partly in agreement with the defense signaling hypothesis as well as the cuticle hypothesis, since one of the main functions of the cuticle is to protect the plants from pathogens.

Some nsLTPs have been found forming complexes with other proteins. One example is in tomato, where an nsLTP was shown to be necessary for the function of polygalacturonase, a 
protein involved in fruit ripening (Tomassen et al., 2007). In a similar manner, another nsLTP from Arabidopsis have been shown to bind calmodulin in vitro (Wang et al., 2005). Further, other nsLTPs seem to be involved in sexual reproduction, specifically in pollen tube growth and pollen tube adhesion, possibly by forming an adhesive matrix together with pectin (Park and Lord, 2003). There is also evidence of nsLTPs required for normal pollen development, where plants lacking functional nsLTPs showed collapsed pollen grains or irregularities in the sporopollenin coat (Zhang et al., 2010; Chen et al., 2011). NsLTPs have also been found necessary for the symbiotic relationship between cowpea, barrel clover and their respectively symbiotic partners (Krause et al., 1994, Pii et al., 2009).

The widely shifting hypotheses regarding the function of nsLTPs indicate a large functional divergence. However, there seems not to be a clear relationship between proteins of the same type and the function. Further, some of the proposed functions do not obviously involve any lipids, which would be expected by a lipid transfer protein. Clearly, further studies are required to fully understand the function and complexity of these elusive proteins.

\section{The Model Organisms}

For the in vivo experiments we have mainly used two different model organisms: The moss Physcomitrella patens and the flowering plant Arabidopsis thaliana, but tobacco (Nicotiana tabacum), a liverwort (Marchantia polymorpha), a spikemoss (Selaginella moellendorffii) and yeast (Pichia pastoris) were also used in some experiment. For in silico analyses, we have used several species of red and green algae (Mesostigma viride, Volvox carteri, Chlamydomonas reinhardtii, Ostreococcus lucimarinus, Ostreococcus tauri, Cyanidioschyzon merolae and Porphyra yezoensis), maidenhair fern (Adiantum capillus-veneris), loblolly pine (Pinus taeda) and rice (Oryza sativa) in addition to the organisms used for in vivo experiments (Fig. 5). The organisms were chosen to represent as many phyla or divisions as possible from the plant kingdom, but also to have a sufficient number of sequences in EST and DNA databases. Further information is only given about the two main model organisms used, Physcomitrella and Arabidopsis. 


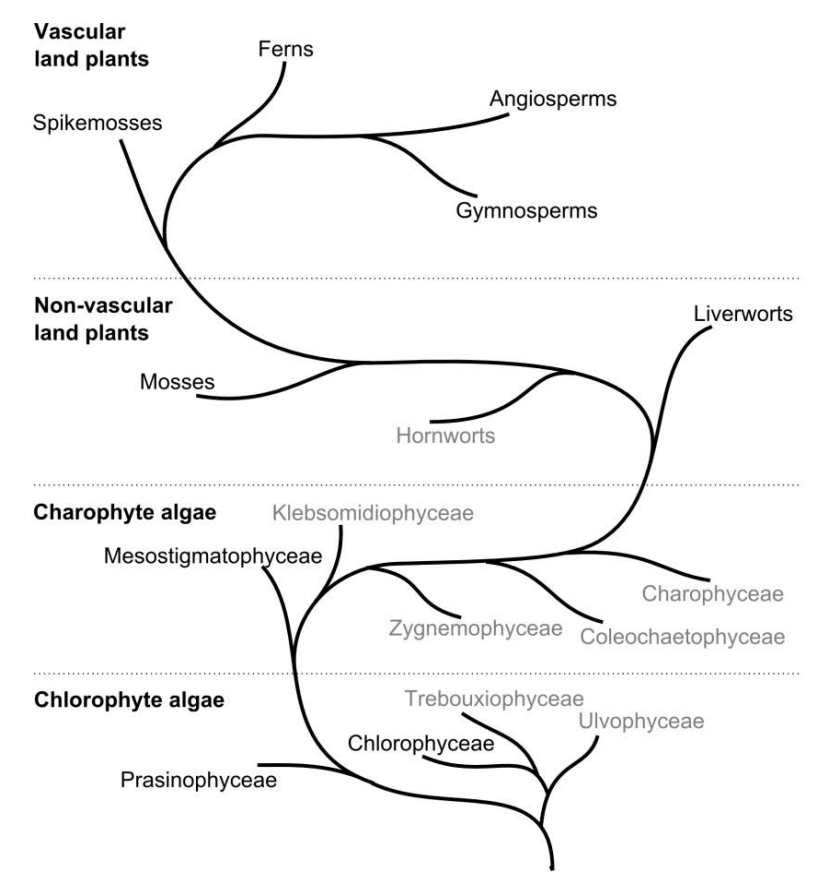

Figure 5. A tree showing the different classes in the plant kingdom. Classes represented in our studies are written in black and those not represented in grey. The figure is a modified version of Fig. 6 from Paper I.

\section{Physcomitrella patens}

The moss Physcomitrella belongs to the division Bryophyta, and is the most early diverging land plant that has a fully sequenced genome (Rensing et al., 2008). This puts it in an interesting position for studies of how plants first conquered land, as well as of the evolution of plants. Phylogenetic studies of when, during evolution, a family of proteins has risen, diverged and maybe disappeared are of course also useful, and here play Physcomitrella an important role due to its strategic location in the tree of life. Other even more interesting species for studying the plant land transition would be charophyte green algae and liverworts, but none of them have a sequenced genome published yet.

The genome of Physcomitrella consists of about $480 \mathrm{Mb}$ arranged in 27 chromosomes (Rensing et al., 2008). There are no chromosome maps available, but around 2000 scaffolds of assembled genomic DNA sequences. Further, the databases includes more than 38000 predicted proteins and almost 400000 raw expressed sequences tags (ESTs) (Lang et al., 2005). 
There are several advantages in using Physcomitrella instead of other common model organisms, such as Arabidopsis or rice. One lies in the life cycle of mosses; their dominant stages of life are haploid, which eliminates the need of producing homozygotes when working with mutants (Reski, 1998; Schaefer and Zrÿd, 2001). After germination haploid spores are formed, which later develop into chloronema. Chloronema is filamentous tissue with a high amount of photosynthetic chloroplasts. Chloronema exists together with caulonema and together they are called protonema (Fig. 6). Caulonemal cells have less chloroplasts than chloronemal cells, but they have the ability to grow gametophores. The gametophores are leafy tissues with root-like rhizoids, and they also harbor the gametes.

Spores, protonema, rhizoids, gametophores and gametes are all haploid gametophyte tissues. After fertilization zygotes, and later sporophytes, are formed. These are the only diploid tissues in Physcomitrella. However, sexual reproduction of Physcomitrella is not necessary since it also has the ability the reproduce asexually by dividing. This is for example ideal when you want to obtain homogenous cultures.

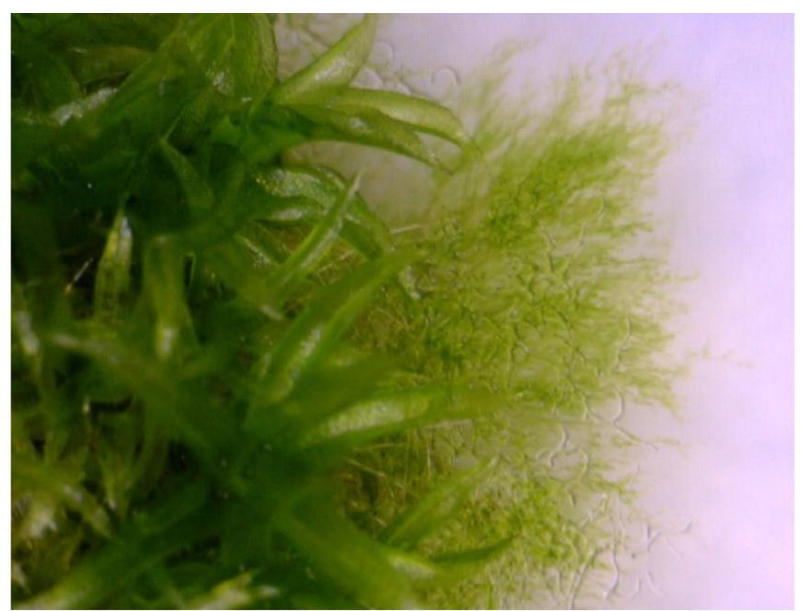

Figure 6. The moss Physcomitrella Patens. To the left is the leafy gametophores and to the right the filamentous protonema.

Another advantage is that Physcomitrella can be grown at culture plates or in liquid cultures for the whole life cycle and never needs to be cultivated in soil. This leads to more controlled growth conditions and minimal risk of contamination. The composition of the medium can easily be changed whenever desired. This is for example used for stress experiments, to 
stimulate gamete formation or to alter the ratio of gametophore and protonemal tissue (Schween et al., 2003; Cove et al., 2009).

The most obvious advantage with Physcomitrella over other model plants is however the high homologous recombination that occurs in the moss (reviewed by Schaefer, 2001). Due to this, transformation of the moss genome can be performed without the use of agrobacterium or other hosts that are required for most other plants. Since the transformation is performed in the protoplast, the achieved mutation affects the whole plant arisen from that cell. The method, called gene targeting, can be used to make replacements as well as insertions, leading to an enormous amount of possibilities (reviewed by Schaefer, 2002).

Physcomitrella is less complex than later diverging plants in terms of morphological structures, lacking for example true vascular system, flowers, seeds and roots. This is an advantage when examining a proteins function, as long as the protein of interest is still present. The presence or absence of nsLTPs in Physcomitrella has not yet been investigated. Even though it is less complex, Physcomitrella still has enough similarities to higher plants to be a useful model plant. Many proteins are conserved, the hormone systems are most probably identical and the cells have the same construction (Cove et al., 2006). Physcomitrella is very tolerant to drought and other stresses, but it is not yet known if this is due to a protective cuticle (Frank et al., 2005).

\section{Arabidopsis thaliana}

Arabidopsis thaliana (also known as thale cress or mouse-ear cress) is a well-established model organism; the most studied one within the plant kingdom. The plant belongs to the mustard family and appears unpretentious with small white flowers, tiny seeds and thin stalks (Fig. 7). Even though it is edible it has no value for cultivation and it is thus not domesticated. Arabidopsis is native to Europe, North Africa and Asia, where several different ecotypes are found in the different areas (Meyerowitz and Somerville, 1994).

Arabidopsis is easy to germinate, maintain and propagate in labs or greenhouses, demanding small space and relatively little attention (Meinke et al., 1998). Seeds can be sown either directly on soil, or on agar plates for more controlled growth conditions. However, only small seedlings can be grown on agar plates, they must then be transferred to soil to cover all life stages. The bolting will occur within three weeks after germination and mature seeds can be collected a couple of weeks later. Arabidopsis is an annual plant and senescence occurs shortly after maturation of the seeds. 


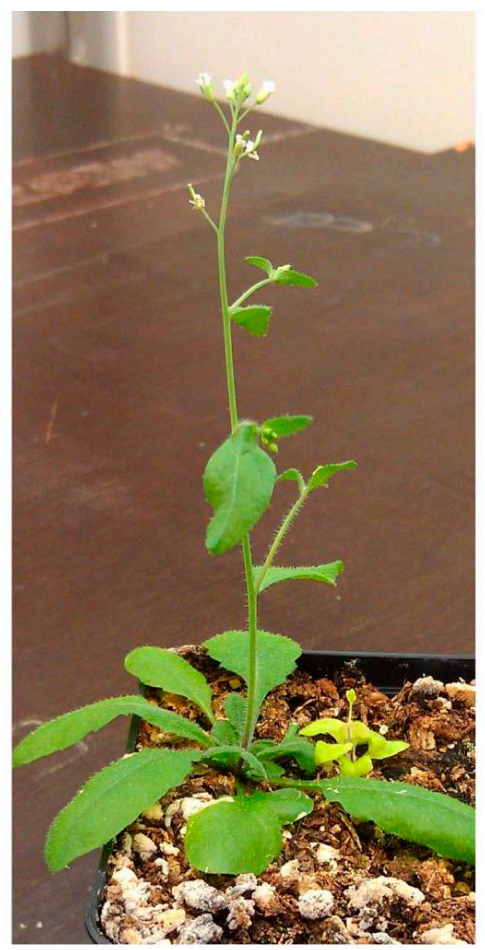

Figure 7. An Arabidopsis wild-type plant of ecotype Columbia to the left and a small, pale mutant to the right

Except for the short lifecycle and the ease to handle, there are several more advantages with Arabidopsis that made it to the plant model organism number one: It is self-pollinating, easy to transform and have a relatively small genome (Loyd et al., 1986; Pruitt and Meyerowitz, 1986; Abbott and Gomes, 1989; Clough and Bent, 1998). Due to the self-pollinating feature, there is no need for time-consuming pollination. Further, this means that a plant homozygous for any trait will only produce offspring homozygous for the same trait. Artificial pollination is however possible and commonly used to obtain crossings between different lines.

In Arabidopsis there is not, in contrast to Physcomitrella, an efficient homologous recombination, so it is not possible to use direct transformation in order to obtain mutants. Instead the transformation usually is mediated by the plant pathogen Agrobacterium tumefaciens (Loyd et al., 1986; Clough and Bent, 1998). Agrobacterium infects plants by inserting a short DNA fragment (known as transfer DNA or T-DNA) into the plants' genome. The T-DNA agrobacterium use for this purpose is found in a plasmid, which can be altered to contain any DNA of interest. Unlike transformation of Physcomitrella through homologous 
recombination, agrobacterium mediated transformation is not site specific but will occur at random positions in the genome (Chyi et al., 1986). The method is used to disrupt random genes in order to achieve knockout mutants, and there is now a large library of T-DNA insertion mutants available in Arabidopsis (Sessions et al., 2002; Alonso et al., 2003).

The Arabidopsis genome was the first plant genome to be fully sequenced, completed in the year 2000 (Arabidopsis Genome Initiative, 2000). The genome consists of about $157 \mathrm{Mbp}$, distributed on five chromosomes, and contains 27000 genes encoding 35000 proteins (including different isoforms). Many of the genes and proteins have been extensively studied and there exist several public databases and tools handling gene expression, protein function and other related areas, making Arabidopsis suitable for in silico analyses (Rhee et al., 2003; Zimmermann et al., 2004; Sakurai et al., 2005). 
-20 - 


\section{Aims}

The overall purpose with this thesis was to achieve a deeper understanding of the function of nsLTPs in plants, by studying evolution, expression patterns, lipid binding ability, stability and knockout mutants of these proteins.

\section{Paper I - Evolution}

The aim with Paper I was to find out when, during plant evolution, the nsLTPs had arisen. This was done by examining the presence or absence of nsLTPs in organisms from different phyla in the plant kingdom. By comparing green algae with land plants, one can determine whether the protein is important for land colonization, comparison between vascular and nonvascular plants gives clues about involvement in the vascular systems, and so on. Except for the functional aspect, another aim with this paper was to bring order in the classification of different types of nsLTPs. The previously used classification system was based only on nsLTPs from flowering plants.

In addition to this, the purpose with this paper was also to examine if Physcomitrella would be a suitable model organism for further nsLTP investigations. In the less complex organism you would expect a smaller, and thus more manageable, number of nsLTPs.

\section{Paper II - Characterisation of LTPGs in Physcomitrella}

In Paper II we have focused on the LTPGs found in Physcomitrella in Paper I. The aim was to characterize these newly discovered proteins, in aspect of lipid binding capacity, expression pattern and protein stability. The main purpose was to find out if some of the nsLTPs in Physcomitrella seem to be functional homologs with those in late diverging plants, like Arabidopsis. To be able to conclude whether the nsLTPs in Physcomitrella could be involved in formation of the cuticle, the presence and lipid content of the moss cuticle was examined, aiming to find an agreement between the content and the lipid binding capacity of the nsLTPs.

\section{Paper III - Expression}

In Paper III we constructed networks of coexpressed nsLTPs from Arabidopsis and rice. These networks were then used in genome wide searches for coexpressed genes with the aim to this 
way gather further clues about the function of nsLTPs, taking advantage of the fact that genes involved in the same biological processes usually are expressed similarly. Further, we manually examined the expression pattern for each module, regarding e. g. tissue specificity and stress impact.

In addition to this, we investigated the occurrence of alternative splicing among the GPIanchored nsLTPs in Arabidopsis. It has previously been shown that alternative splicing affecting the GPI-anchor signal occur in other protein families, leading to loss or alternation of the protein function.

\section{Paper IV - Knockout mutants in Arabidopsis}

The aim with Paper IV was to further investigate the in vivo functions of the GPI-anchored nsLTPs in Arabidopsis. This goal was achieved by studying knockout mutants of several of the genes in different ways, and comparing the results with those of wild-type Arabidopsis. Guided by the results from Paper III, we examined the knockout mutants regarding cuticle permeability, pollen development, seed coat permeability and stress tolerance, with the objective to find any differences between the mutants and the wild-type that could give further clues about the function of these proteins. 


\section{General Methods}

\section{Bioinformatics}

\section{Sequence Alignment}

In order to compare different nucleotide or amino acid sequences they need to be aligned. In a pairwise alignment only two sequences is compared and residues similar in both sequences are aligned to each other. This is usually performed globally; for each position in the whole sequence. The similarity between two residues is determined by a substitution matrix, e. g. the Point Accepted Mutation (PAM) Matrix or the Block Substitution Matrix (BLOSUM) (Dayhoff et al., 1978; Henikoff and Henikoff, 1992). Further, the alignment score gets reduced when insertions or deletions is needed in any of the sequences, by so called Gap Penalties (Lesk et al., 1986). The more similar two sequences are, the higher score do they get. Since the maximal possible score is dependent on the length of the sequences, the absolute score is in general not useful. Instead the percentage of identical residues in alignments is of interest. In general, two aligned amino acid sequences having more than $30 \%$ identical residues are considered as related.

However, pairwise alignments are in general not very useful. Instead, aligning several sequences to each other at the same time is more desirable (Fig. 8). When aligning multiple sequences the most commonly used tool is CLUSTAL, a program using the progressive multiple alignment method (Higgins and Sharp, 1988). The method starts by aligning the two most similar sequences in a pairwise manner and then progressively adds the other sequences, ending with the least similar one (Feng and Doolittle, 1987). The similarity between each pair of sequences in the alignment is given in a matrix. Further, multiple alignments are often used to construct phylogenetic trees.

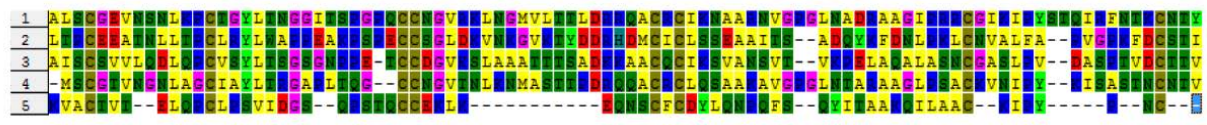

Figure 8. A multiple sequence alignment of five nsLTP sequences from Arabidopsis. Identical or similar amino acids are aligned and gaps are inserted when needed.

\section{Phylogenetic Trees}

A phylogenetic tree shows the computed relationship between e.g. proteins or species in a tree-like way (Fig. 9). Most methods used to construct a phylogenetic tree based on sequence data needs a multiple alignment as input, including the neighbor joining (NJ) and Maximum 
Likelihood (ML) methods (Felsenstein, 1981; Saitou and Nei, 1987). In the NJ method each sequence is paired to the sequence it is most closely related to - the neighbor. When all sequences are paired a treelike structure is obtained, where closely related sequences are sharing the same node. The NJ method is much faster than for example the ML method. The ML method uses a model tree and then recalculates it to fit the input data in the best possible way. The ML method is often more appropriate than the NJ method when dealing with distantly related sequences.

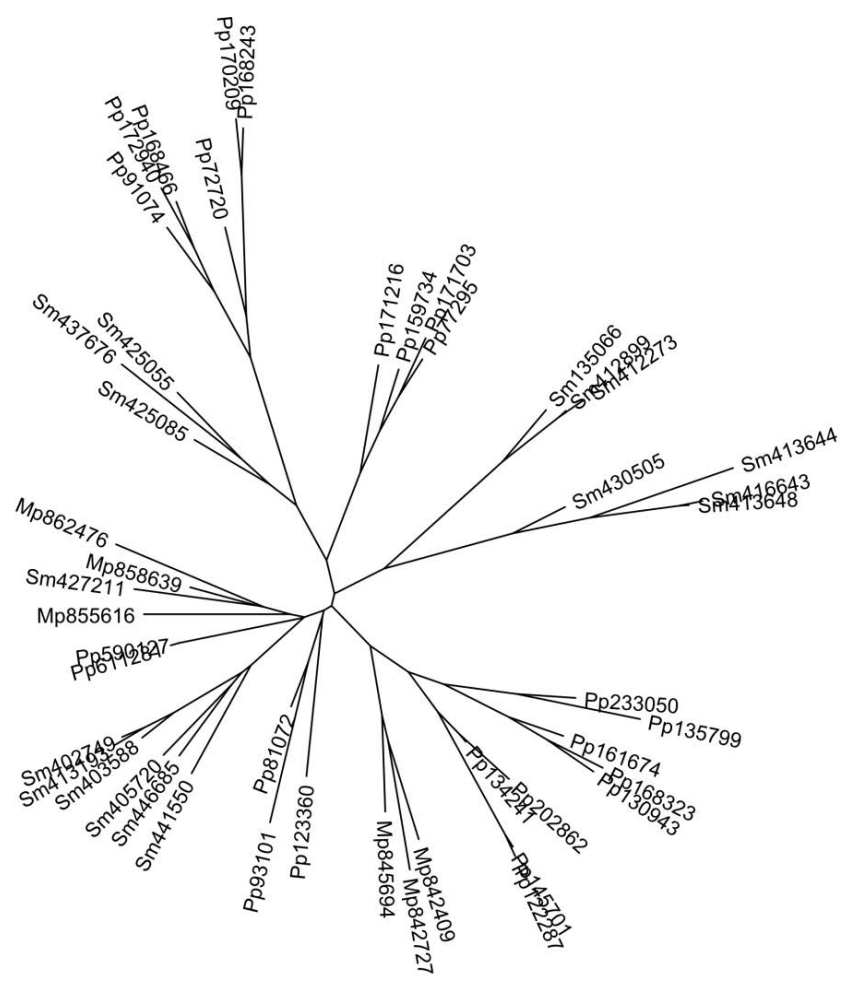

Figure 9. An example of a phylogenetic tree, in this case constructed using the ML method. This tree is unrooted, thus it has no direction and can not be used to draw conclusions about ancestry, but to determine relationships between the proteins.

\section{Basic Local Alignment Search Tool}

The Basic Local Alignment Search Tool (BLAST) is a tool used to search databases in order to find nucleotide or amino acid sequences similar to the input sequence (Altschul et al., 1990). As the name indicates, the tool uses local alignment to find the similarities, compared to the global alignment that is used for common pairwise or multiple sequence alignments. The tool first searches the database for a short sequence (called word) of residues identical to 
those in the query sequence. Everywhere these words are found the local alignment is extended in both directions, resulting in an alignment covering all identical or similar residues, depending on settings. This way it is possible to search very large databases fast.

\section{Coexpression Networks}

For Arabidopsis there are microarray data available that includes almost every gene in the genome. The expression has been determined during different developmental stages, stresses, chemical treatments and from various tissues (Schmid et al. 2005; Kilian et al. 2007; Winter et al. 2007; Goda et al. 2008). These datasets can be used to calculate the correlation coefficient between any pair of genes present among the data. A high correlation coefficient indicates that the genes are coexpressed in the given dataset, while a negative value indicates an anticorrelation. When connecting every pair of genes with a correlation coefficient above a given threshold, a network of coexpressed genes is retrieved. This is useful due to the fact that genes involved in the same pathways and processes often are simultaneously expressed (DeRisi et al., 1997; Stuart et al., 2003). Thus, clues about a gene's function can be gathered by looking at the function of genes found in the same coexpression network.

\section{Gene Ontology Enrichments}

When constructing coexpression networks with multiple input genes, they easily grow too large to be possible to interpret by hand. One way of dealing with this problem is to search for enrichments in Gene Ontology (GO) terms. All genes with known functions in the Arabidopsis genome are annotated with several GO terms, related to their function and localization (Berardini et al., 2004). Terms enriched in a network can be found by comparing the occurrence of the term in the network with that in the whole genome. A significant enrichment of a GO term in a network indicates that the genes in the network may be involved in processes related to that term.

\section{PCR and qPCR}

Polymerase Chain Reaction (PCR) is a method to amplify a DNA fragment of interest, for detection, sequencing or other molecular techniques. The method uses the enzyme DNA Polymerase, which has the ability to synthesize a DNA strand complementary to a template strand when offered a free 3'-OH group and nucleotide building blocks (Saiki et al., 1988). To create the free 3'-OH groups two primer sequences are used, complimentary to a stretch of DNA at both sides of the fragment of interest, at one strand each. By heating up the DNA, the two strands are separated; the DNA denatures. This is followed by a decrease in temperature, 
where the primers bind to the complementary DNA. During the following elongation step the polymerase synthesizes a new strand. By repeating these steps several times an exponential increase of the fragment is achieved. The fragment can then be visualized on a gel for detection. Quantitative PCR (qPCR) uses the same principle, but with a modification; a fluorescent dye (e.g. SYBR Green) is added to the sample (Chiang et al., 1996). When using SYBR Green, the dye binds double stranded DNA and by measuring the fluorescence after each PCR cycle the amount of DNA in the sample can be determined. The method is commonly used to compare the amount of cDNA of a gene in different samples.

\section{Fusion Proteins}

Fusion of a reporter gene to another gene is a common method used to detect the expression pattern or localization of the gene of interest (GOI). The reporter gene is a gene that is easy to visualize by e.g. fluorescence or specific staining. By fusing the reporter gene to the promoter of the GOI it is possible to detect in what tissues the promoter is active, and thus the GOI is expressed. This is however not suitable for studying the subcellular localization of the GOI, since that depends on signal sequences in the gene and not the promoter activity. For that purpose it is better to fuse the reporter gene directly to the open reading frame of the GOI, preferably in the 3' end since most signal sequences are found in the 5' part. These constructs can either be under the control of the promoter of the GOI or by another promoter known to be highly expressed, e. g. the cauliflower mosaic virus 35S-promoter. The fusion proteins are usually constructed in a plasmid, which enables cutting and ligation of DNA by enzymes. If stable transformants are required a resistance gene is also inserted in the plasmid, to make selection by antibiotics possible.

We have used two different reporter gene systems to study the expression of LTPGs in Physcomitrella; $\beta$-glucuronidase (GUS) and Yellow Fluorescent Protein (YFP). The GUS protein cleaves the substrate 5-bromo-4-chloro-3-indolyl glucuronide (X-gluc), resulting in a blue precipitation in the tissues where the gene is expressed, while YFP is fluorescent and can be visualized in vivo under visible light, without any need of staining. We used the promoter of the GOI for the GUS assay and the 35S promoter for the YFP assay, since we were interested in the expression patterns in different tissues with the first construct and the subcellular localization with the later. 


\section{Transformation of Physcomitrella}

As mentioned before, Physcomitrella have a high frequency of homologous recombination that makes it suitable for transformation. Only young protonemal cells can be used, and their cell walls must be enzymically digested before the transformation can take place. The obtained cells without cell walls are called protoplasts. When heat chocked in presence of polyethylene glycol the protoplasts are able to intake the external DNA (Schaefer, 1991). The DNA can then be incorporated into the genome by homologous recombination (Fig. 10). The larger part of the transformants will however be unstable, with the cloning cassette outside of the genome. These are only useful to study the subcellular localization of the GOI, and only when a promoter is included in the construct. To detect the stable transformant, obtained by homologous recombination, the moss has to be grown alternately on selective and nonselective medium. During growth on non-selective media the unstable transformants will discard the cloning cassette since it is not necessary. During the next cycle of growth on selective media they will not survive and thus only the stable transformants are retained.

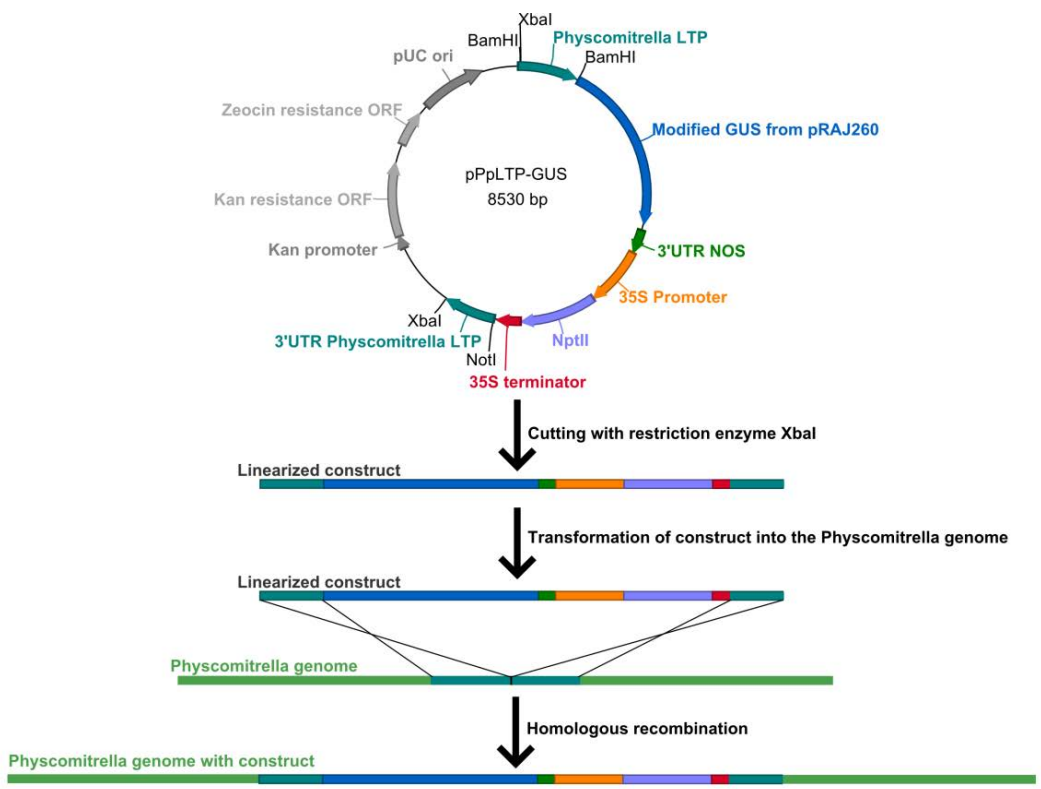

Figure 10. How to use homologous recombination for gene targeting in Physcomitrella. The plasmid shows a LTP-GUS fusion, where the two Physcomitrella sequences (cyan) will be used for recombination. Parts in grey are only needed for growth in bacteria and thus removed (by cutting with restriction enzyme XbaI) before transformation into Physcomitrella. The resulting linear construct is transformed into Physcomitrella where it reaches the chromosomes. The end sequences of the construct will align to the identical sequences in the Physcomitrella genome. When homologous recombination occur the whole construct is incorporated into the genome. In this case the gene encoding GUS will be expressed together with a nsLTP gene. The NptII gene is under control of the $35 \mathrm{~S}$ promoter and provides kanamycin resistance for selective growth of successful mutant plants. 


\section{Transformation of Tobacco}

As in the case of Arabidopsis, tobacco has a too low frequency of homologous recombination to use this for transformation. Instead the agrobacterium-mediated transformation must be used (Caplan et al., 1983). We used this system to transform the YFP-LTP fusion protein into tobacco, in order to study the subcellular localization.

\section{Heterologous Protein Expression in Yeast}

The yeast Pichia pastoris can be used to express proteins from other species - heterologous expression. An advantage with yeast compared to $E$. coli is that yeast is a eukaryote and is thus capable of post-translational modifications, including formation of disulphide bonds and phosphorylation of some amino acids. The other yeast strain commonly used for heterologous expression, Saccharomyces cerevisiae, does not have the phosphorylation ability. Further drawbacks with $S$. cerevisiae are a low protein yield and hyperglycosylation of the expressed protein.

The basic principles of the Pichia expression system are the same as in E. coli; the gene to be expressed is put in an expression vector and transformed into the yeast. The expression vector can have different configurations, but it is common to have a sequence for secretion of the expressed protein. Protein expression is induced by addition of methanol to the growth medium.

\section{Circular Dichroism}

Circular dichroism (CD) is a method where circularly polarized light is used to study for example secondary structures in protein molecules (Greenfield, 2006). Basically, how the light is absorbed depends on the structure of the molecules it hit. For example, a protein consisting of $\alpha$-helices gives another spectrum than one consisting of $\beta$-sheets or random coil. We used this method to study the stability of Physcomitrella nsLTPs expressed in yeast, by exposing them to increasing temperatures during the $\mathrm{CD}$ measurement.

\section{Lipid Binding Assay}

One way of studying the in vitro lipid binding ability of a protein is to use the fluorescent molecule 2-p-toluidinylnaphthalene-6-sulphonate (TNS). TNS only emits fluorescence when it is found in a hydrophobic environment, like the lipid binding cavity of an nsLTP, but not in an aqueous solution (Beyer et al., 1973). Since nsLTPs are known to bind TNS, this can be 
used to study binding of other lipids. A reduction in the fluorescence emitted from TNS following the introduction of another lipid indicates that the protein has a higher affinity for the other lipid, compared to that of TNS. This method can thus be used to examine the lipid binding ability of a protein, and to study the affinity for different lipids.

\section{Tetrazolium Staining}

2,3,5-triphenyl-2H-tetrazolium chloride (TTC) is a colorless molecule, soluble in water. When it comes in contact with living tissues the TTC is reduced into the red compound 1,3,5triphenylformazan (TPF). Tetrazolium staining is thus often used to distinguish between dead and living tissues (Porter et al., 1947). Another way of using tetrazolium staining is to examine the seed coat permeability of Arabidopsis seeds (Debeaujon et al., 2000). The intact seed coats of wild-type seeds are not permeable by tetrazolium, thus the seeds are not stained when exposed to the dye. If the seed coats are defect TTC can enter the seeds, where it is reduced to TPF that stains the embryos red. The amount of formazan in the seeds, and thereby the permeability, can be quantified by using a spectrophotometer. This is a commonly used method to identify mutant lines with defect seed coats, prior to further investigations.

\section{Gas Chromatography-Mass Spectrometry}

Gas Chromatography-Mass Spectrometry (GC-MS) is a method used to identify and quantify compounds in a sample. The GC separates different compounds according to size and molecular properties, while the MS is used for detection (James and Martin, 1951; Dalgliesh et al., 1966). Together they produce a chromatogram with fingerprints for each compound. The chromatogram is given by the GC and is basically a timeline with peaks representing the different compounds. The higher the peak, the more of that molecule is found in the sample. Every molecule has a unique fingerprint, determined by the MS. These fingerprints together with the molecules retention time (where the peak appear at the timeline) is used to identify the compounds, while the peak area is used for quantification. GC-MS can be used to identify most molecules, including lipids.

\section{Scanning Electron Microscopy}

Scanning Electron Microscopy (SEM) is a method used to study surfaces in high magnification. Electrons, emitted from an electron gun in the microscope, interact with electrons on the surface of the sample (Hayes and Pease, 1968). This leads to an energy loss and an emission of slow moving secondary electrons, which are detected, amplified and used to create an image. Since molecules in the air would disturb the signal, the observations must 
be done under vacuum. Further, the sample must be conductive to electricity, wherefore it is sputtered with an ultrathin layer of metal (e. g. platinum) ahead of examination in the microscope. 


\section{Results}

\section{Paper I - Evolution}

The main finding in Paper I was that nsLTPs are present in all investigated land plants, but not in any of the green algae. In the most early diverging land plant studied, the liverwort Marchantia, there were at least 14 nsLTPs, indicating an important role for life on land. There were as many as 40 in the moss Physcomitrella, 43 in the spikemoss Selaginella, six in the fern and 43 in the pine. Further, we discovered that members of the two most studied nsLTP types, Type 1 and Type 2, only are found in flowering plants (both types) and ferns (Type 1). This indicates a role for proteins of these types in structures not found in the earliest diverging plants, for example in the vascular system or flower. The earliest nsLTP types, found in all land plants, seem to be Type D and Type G. Due to sequence and structure similarities we propose that these two types probably have a common origin, but that the genes in Type $\mathrm{G}$ have gained a GPI-anchor signal. A total of ten different types of nsLTPs were found and classified in Paper I. Four of them (Type 1, 2, D and G) were considered major types and were found in several species, while the remaining six were minor and only found in one or a few. We also developed a new classification system for the nsLTPs since the present system, mainly based on the length of the sequence between cysteines, was not applicable to nsLTPs from early diverging plants. The new system is based on a combination of the distances between cysteines, the presence and position of the conserved intron, presence of a GPIanchoring signal and sequence similarity. By using this system most nsLTPs can be put in the correct type without examining the sequence similarity towards nsLTPs of known types. Further, the phylogenetic trees we constructed revealed that nsLTPs from the same species tend to cluster together within a type, especially when considering the early diverging plants. This could indicate that duplications in the nsLTP family occurred independently in the different species.

A total of 40 nsLTPs were found in Physcomitrella, of which 21 belong to Type D and ten to Type G. The remaining nine belong to minor types only present in the moss. Physcomitrella would thus be a suitable model organism for further investigations of the Type D and G nsLTPs, while it is not possible to use for studies of Type 1 or Type 2 nsLTPs due to their absence. 


\section{Paper II - Characterization of LTPGs in Physcomitrella}

In Paper II we could conclude that the LTPGs in Physcomitrella in many aspects resemble those in late diverging plants. The expressions of several of the genes were affected by different stresses, including dehydration, cold and salt stress. However, a downregulation was seen more frequently than an upregulation. Fusion proteins of four of the LTPGs and the GUS reporter gene revealed an expression in rhizoids, protonemal tissue and gametophores, but with different expression patterns in the four constructs. The fusion of one LTPG gene to the YFP reporter gene and the subsequent expression in moss protoplasts and tobacco leafs indicated an extracellular localization close to the plasma membrane, which is in agreement with their localization to cell walls in other studied plants. Further, heterologously expressed LTPGs were shown to be very heat stable with denaturation temperatures above $88^{\circ} \mathrm{C}$. The lipid binding assay revealed that two LTPGs from Physcomitrella were capable of binding different lipids, including the fluorescent probe TNS and several unsubstituted C18 fatty acids. There was no significant difference in the affinity between the two investigated proteins; both showed a rather low affinity for the saturated C18:0, but it increased substantially when the unsaturated $\mathrm{C} 18: 1$ and $\mathrm{C} 18: 2$ were used. When C18:0 was bound to Coenzyme A the affinity increased to the level of C18:1 and C18:2. One $\omega$-hydroxylated fatty acid was used in the assay: $\mathrm{C} 22 \omega \mathrm{OH}$, but it was bound to the nsLTPs with low affinity.

The presence of a cuticle in the moss was examined, in order to be able to draw any conclusions about the LTPGs' possible involvement in the construction of that structure. The result showed that Physcomitrella indeed possess a cuticle, or at least a protecting lipid layer. We could identify unsubstituted fatty acids with chain-lenths ranging from 16 to 24 carbons, both saturated and unsaturated. The majority of the unsubstituted fatty acids were $\mathrm{C} 16$ and C18, which is the case in most plants. The dicarboxylic acids were not found at all. The only fatty alcohol found was $\mathrm{C} 18 \mathrm{OH}$, but there was also one triol of the same length. Similarly, only one chain-length was found among the $\omega$-hydroxylated fatty acids as well - C16, which constituted less than $3 \%$ of the total lipids. However, the dihydroxylated C16 was found in a high amount - approximately $21 \%$. 


\section{Paper III - Expression}

Three networks of coexpressed LTPGs could be found in both Arabidopsis and rice, and their expression pattern and phylogenetic relationship indicate that they are equivalents. There was no close phylogenetic relationship between the coexpressed genes within a species. This is unusual since more closely related proteins tend to be involved in the same biological processes. In the case of LTPGs, a close relationship may then indicate similar lipid binding preferences rather than involvement in the same process.

When expanding the networks of LTPGs to include genes from the whole Arabidopsis genome, the three modules were clearly pointing in different directions regarding putative functions. Module AtI was coexpressed with genes involved in photosynthesis, abiotic stress and wax biosynthesis, which indicates a role in cuticle formation. For module AtII, enriched GO terms included response to stress, suberin biosynthetic process and root development, while they were mostly related to pollen wall assembly and sporopollenin synthesis for module AtIII. We thus proposed that the genes in AtI, AtII and AtIII are involved in biosynthesis or transfer of molecules to cutin, suberin and sporopollenin, respectively. These hypotheses were also strengthen by the expression pattern in different tissues and developmental stages. In addition to this, we conducted a search for overrepresented motifs in the promoter regions of the genes for each module. The result showed several similarities between the modules, for example promoter elements related to light signaling and leaf senescing were found in all modules. However, there were some differences as well; promoter motifs related to leaf development were only found in AtI, those related to the phenylpropanoid biosynthetic pathway (involved in suberin synthesis) were only found in AtII while motifs related to the circadian clock only were found in module AtIII.

Further, in silico investigations of transcripts encoding LTPGs showed indications of alternative splicing in nine of the 34 genes. By examining this in planta we could show that different isoforms indeed occurred among the transcripts for all four genes investigated. We used two different growth conditions; normal and constant light and examined four different tissues (leaf, flower, silique and root). Our results showed that the expression of the isoforms varied between different tissues and growth conditions. For all four genes at least one isoform was missing the GPI-anchoring signal, leading to the expression of anchor-less proteins. 


\section{Paper IV - Knockout mutants in Arabidopsis}

The most important results in Paper IV are the changes in phenotype regarding pollen and seed coat in several of the knockout mutant lines, compared to wild-type. Two of the lines, both found in the pollen-related module AtIII in Paper III, showed a phenotype with collapsed pollen grains together with an increase of unfertilized ovules, indicating a reduced pollen function. These results indicate a defect in the construction of the pollen exine, which could be due to altered sporopollenin composition. Further, several lines showed increased seed coat permeability in the tetrazolium staining assay, compared to wild-type. SEM was used to study the surfaces of the seeds, without being able to fully explain the increase in permeability. However, several seeds were shown to have strange hair-like outgrowths. A GC-MS analysis of the seed coat suberin in two of the mutant lines revealed an alternation in the lipid composition compared to wild-type. The main differences were a decrease in $\omega$-hydroxylated fatty acids and an increase in unsubstituted fatty acids. The $\omega$-hydroxylated fatty acids play an important role in suberin through their participation in ester bonds. Thus, this alternation in lipid composition probably caused the increase in seed coat permeability. Interestingly, none of the two mutant lines with this phenotype were complete knockouts; the first part of the genes was still expressed, only the GPI-anchoring signal was missing. This indicates that the GPI-anchor is necessary for the function of the LTPG.

Besides these results, the mutant lines showed normal phenotypes in most aspects; there was no decrease in germination rate and the stress tolerance was similar to that of wild-type. The pollen viability was normal in the examined lines, and all lines showed a normal secretion during imbibition. Neither could we find any indications of increased cuticle permeability in any of the mutant lines. 


\section{General Discussion}

The fact that the nsLTPs are present and highly abundant in all land plants suggests that they became important when plants first conquered land. For land plants, in opposite to green algae, dehydration is one of the main threats. To deal with this plants have developed a protective barrier - the cuticle. The cuticle is found at the surfaces of aerial parts of the plant and consists of waxes and the polymers cutin and cutan (Boom et al., 2005; Samuels et al., 2008). Except for protection against dehydrating and radiation, the cuticle has several other putative functions: It functions as a barrier, keeping harmful microorganisms and chemicals out, and controls gas exchange (Jenks et al., 1994; Boyer et al., 1997). Further, the cuticle has antibiotic properties and helps to prevent organ fusions (Luo et al., 2007; Smith et al., 2007; Weng et al., 2010). Thus, it is a structure vital for a plant's survival on land.

The lipid composition of cutin varies in different plant species and tissues, but generally the main components are $\omega$-hydroxy fatty acids and substituted $\omega$-hydroxy fatty acids together with glycerol (Kolattukudy, 2001). Minor components are unsubstituted fatty acids, 1, $\omega$ dicarboxylic acids and fatty alcohols. The monomers are probably synthesized in the endoplasmic reticulum (ER) and transported to the plasma membrane, where $\mathrm{ABC}$ transporters are known to move lipids across the membrane (Pighin et al., 2004; Bird et al., 2007; Pollard et al., 2008). Since the cuticle is located outside the cell wall there must be an additional transporter, able to transfer the hydrophobic lipids across the hydrophilic cell wall. This would be a suitable role for the nsLTPs, and knockout mutants of a couple of LTPGs have altered lipid composition in the cuticle (DeBono et al., 2009; Lee et al., 2009; Kim et al., 2012). This theory is strengthen by our investigation showing that nsLTPs are found in all land plants, together with evidence of a protective lipid layer present in the moss Physcomitrella. This would also explain the high expression of some nsLTPs in epidermal cells in aerial tissues and why nsLTPs are crucial for a life on land. However, our study of LTPG knockout mutants in Arabidopsis did not reveal any differences in cuticle permeability. This may be explained by a functional redundancy among the numerous LTPGs, or a margin of error in the lipid composition of a functional cuticle.

The investigation in Arabidopsis however suggests that the involvement in cuticle formation is not the only function of the LTPGs. Of the three modules of coexpressed genes, one is 
thought to be involved in cuticle formation, while the others might have a similar role in the transfer of lipids to the corresponding protective barriers of root, seeds and pollen: suberin and sporopollenin (Fig. 11). Suberin is mainly found in underground tissues, but also in seed coats, while sporopollenin only is found in the pollen wall (Franke et al., 2005; Ma, 2005; Molina et al., 2006). Compared to cutin, suberin consists of more dicarboxylic acids and fatty alcohols, but less substituted $\omega$-hydroxy fatty acids (Kolattukudy, 2001; Franke et al., 2005; Molina et al., 2006). Unlike cutin, suberin is found on the inner side of the cell wall, close to the plasma membrane (Kolattukudy, 1980). Thus there is no need for transport of lipids through the cell wall, but maybe in the aqueous apoplastic space. Our analysis of the lipid composition of seed coat suberin in two different LTPG mutant lines revealed an increase of unsubstituted fatty acids and a decrease in $\omega$-hydroxylated fatty acids and fatty alcohols. Since the hydroxy-group is necessary for ester bindings in the polymer, this is most likely to affect the properties of suberin. Thus, we were able to provide evidence for our earlier proposed role of some LTPGs in suberin deposition. Since the lipid composition of the cuticle and the suberin layer is rather similar, this is not an unexpected function for the nsLTPs. As in the case of the cuticle the suberin layer has mainly protective roles, but in root and seed instead of leaf and stem. Neither seeds nor roots are present in green algae, but rhizoids for anchoring occur in some of the charophyte algae. The occurrence of suberin in rhizoids of mosses or green algae has not been investigated. The fact that roots and seeds are structures not found in early diverging plants could be a part of the explanation for the large increase in nsLTPs in higher plants. Anyhow, the involvement of nsLTPs in yet another structure crucial for terrestrial life further establishes their position as one of the key inventions in plant evolution.

Sporopollenin is a structure related to cutin and suberin, but only found in the outer wall (exine) of pollen grains (Ma et al., 2005). The monomers of sporopollenin are produced by the tapetal cell layer and then secreted to the exine (Blackmore et al., 2007). Sporopollenin is much less studied than both cutin and suberin, thus the exact lipid composition is not yet known. Further, sporopollenin is highly resistant to chemical degradation, making it difficult to analyze the monomers (Brooks and Shaw, 1968; Loewus et al., 1985). It is thought to consist of similar hydrophobic monomers as cutin and suberin, connected with ester- or ether bonds (Dominguez et al., 1999; Ahlers et al., 2000). As in the case of suberin and cutin monomers, the sporopollenin constituents are probably transported through the plasma membrane of the tapetum cells by ABC transporters (Quilichini et al., 2010; Kuromori et al., 
2011). Then they need to be transported further, through the locule (the pollen-containing chamber in the anther) to reach the developing pollen grains. The locular fluid contains mainly sugars and is probably hydrophilic, making the nsLTPs suitable for the transfer. This hypothesis is supported by the fact that the pollen grains from our sporopollenin-related module showed signs of defect exines. A very similar phenotype has previously been reported in chili pepper after silencing of a nsLTP gene (Chen et al., 2011). Further, a Type D nsLTP from rice have previously been shown to be required for normal pollen wall formation (Zhang et al., 2010). As in the case with the other protective barriers, sporopollenin was first needed when plants colonized earth and started to spread with the wind, which is consistent with our findings of nsLTPs in all land plants. The exine of spores from extant early diverging plants, as well as the cryptospores of the first land plants, is thought to be structural homologs to the exine of pollen grains in higher plants (Olesen and Mogensen, 1978; Kendrick and Crane, 1997a; Wallace et al., 2011).

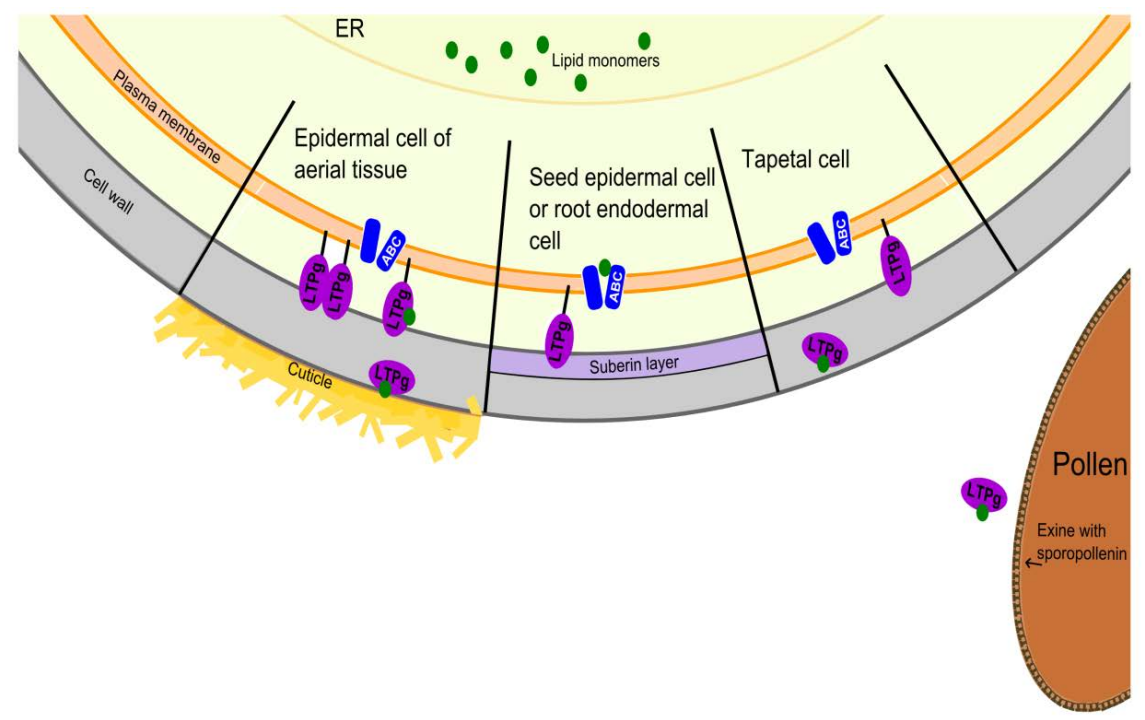

Figure 11. The proposed functions of LTPGs in Arabidopsis. In epidermal cells of aerial tissues, the LTPGs tranfer wax and cutin monomers through the cell wall to the cuticle. In the apoplastic compartment outside the seed epidermal or root endodermal cells the LTPGs transfer suberin monomers to the suberin layer, and in anthers they transfer sporopollenin monomers to the pollen exine from the tapetal cells. When involved in sporopollenin formation, and propably cutin as well, the nsLTPg must be released from the GPI-anchor by phospholipases. 
We have thus designated the genes found in the three coexpression modules different functions, and at least partly confirmed them in vivo by looking at knockout mutants of these genes. Further, the presence of a cuticle in Physcomitrella and sporopollenin in cryptospore fossils indicate that the nsLTPs had the same functions in the first land plants as it has in higher plants, but probably additional functions have arisen through time, leading to the expansion of the protein family. Interestingly, the proteins thought to have similar function are not closely related in a phylogenetic aspect. We therefore speculate that the amino acid similarity rather reflects the lipid specificity than the biological process the protein is involved in. In Paper I we suggested that the different types of nsLTPs were involved in different functions, but findings in Paper III and Paper IV contradict this. The rise of additional types in later diverging plants may instead mirror the more complex lipid composition found in these plants, while the increasing number of members in each type may reflect the need for functions in additional biological processes.

In Physcomitrella four genes were investigated regarding localization in different tissues in the plant. One of the genes was highly expressed throughout the plant, while transcription of the other three were found in a few tissues, suggesting a specific regulation of the transcription. The expression in tips of chloronemal tissue could indicate an involvement in cuticle formation, since this mainly occurs in growing cells. The comparison of the lipid binding ability of LTPGs in Physcomtriella and the lipid composition of the cuticle further supports this theory; the two investigated LTPGs were both capable of binding unsubstituted C18 fatty acids, which are one of the major constituents among the cutin monomers in Physcomitrella.

The corresponding expression in rhizoid tips could then be connected to transfer of monomers to the suberin layer, which presence in Physcomitrella is still not investigated. Unfortunately, the expression of the LTPGs in sporophyte tissue could not be examined, thus no connection between LTPGs and spores could be established. All of the four studied genes were expressed in the midrib of leafy gametophores. These structures are thought to act as primitive vascular tissues, transporting liquids and nutrients, but also supporting the leaf. NsLTPs in higher plants are often found in the vascular system (Rep et al., 2003; Mitton et al., 2009). This localization may be related to their proposed role in long distance signaling.

The expression of LTPG genes in both Arabidopsis and Physcomitrella are mostly under control of promoters related to response to light and different stresses. This is coherent with 
both ours and previous results showing an involvement of nsLTPs in stress responses. Further, genes involved in construction of protective barriers are often upregulated during stress conditions, since reinforcement of the barriers is an important stress response in plants (Schreiber et al., 2005; Cominelli et al., 2008; Kosma et al., 2009).

When investigating the expression of LTPGs in Arabidopsis and Physcomitrella we also found that several of the genes in Arabidopsis, but none in Physcomitrella, were alternatively spliced, resulting in two or three different transcripts of the same gene. This occurred to greater extend when the plants were exposed to constant light compared to normal growth conditions, and thus seem to be a stress response. In several cases some of the transcripts lost their GPIanchoring signal, resulting in both anchored and anchor-less proteins translated from the same gene. The importance of the GPI-anchor for the function of the LTPGs was not previously known, but we could also show a change in phenotype in four different mutant lines in Arabidopsis, where only the part of the gene encoding the GPI-anchoring signal was disrupted, indicating a crucial role of the GPI-anchor. This might be because of a necessity to keep the LTPG anchored close to the ABC-transporter in order pick up the lipids exiting the cell.

\section{Future Experiments}

To further confirm our hypotheses it would be valuable to study knockout mutants of LTPGs in Physcomitrella, to investigate whether they affect the cuticle lipid composition or not. The question of the presence of a suberin layer in Physcomitrella also needs to be addressed, as well as the localization of LTPGs to the sporophytes, to confirm a functional homology between LTPGs in Physcomitrella and higher plants. In Arabidopsis it would be useful to further investigate the LTPGs in vivo by making double-mutants of the knockout mutants we have studied, to see if more severe phenotypes are achieved that way. The suberin composition of roots in our knockout mutants would also be interesting to determine and compare with that of wild-type, to see whether the roots also are affected by the knockout of these genes.

Another valuable investigation would be to address the question with lipid binding affinity in more detail, to find possible differences in the lipid binding preferences among the nsLTPs of different types. 


\section{Conclusions}

The nsLTPs are present in all land plants but not in green algae, suggesting an important role for life on land. We propose that the LTPGs are involved in formation of the protective barriers in plants, including the cuticle, the suberin layer and sporopollenin in the pollen exine. They are most likely to participate in this process by transferring the lipids from the ABCtransporter in the plasma membrane to the barriers. The GPI-anchoring of the proteins seem to play an important role in the process. 


\section{Acknowledgements}

I would like to thank my supervisor, Johan Edqvist, for believing in me and giving me the opportunity to work within this interesting field. I would also like to thank my two others supervisors, Kristina Blomqvist and Jenny Hagenblad, for their support and enthusiasm. I am also grateful to Magnus Eklund for introducing me to the model organism Physcomitrella. Further, I would like to thank all my colleges at the biology department for making these years joyful and memorable. Special thanks to; Jordi Altimiras, for straighten things up; Tove Bjerg, for lending me both knowledge and equipment; Magnus Elfving, for always sharing all the fun stories of his life; Karin Johannesson, for the great company at the gym; Beatrix Agnvall, for her high spirit; Isa Lindgren and Johan Bélteky, for the Friday beers; Martin Johnsson, for knowing everything and always trying the help; Ingevald Abrahamsson, for fixing anything that is broken; Maria Lundström, for the company in the lab; and Hugo Oliveira, for always being nice and sweet.

I would also like to thank Anna Eklöf and Uno Wnnergren for helping us with the cluster analysis, as well as Johan Dahlén and Elke Schweda for teaching me how to operate the GCMS and to analyze the data.

Last but not least I am grateful for the support from friends and family, especially Albin and Axel. 
- 42 - 


\section{References}

Abbott, R.,J. \& Gomes, M.,F. 1989, "Population genetic structure and outcrossing rate of Arabidopsis thaliana", Heredity, vol. 62, pp. 411-418.

Ahlers, F., Bubert, H., Steuernagel, S. \& Wiermann, R. 2000, "The nature of oxygen in sporopollenin from the pollen of Typha angustifolia L", Zeitschrift fur Naturforschung.C, Journal of biosciences, vol. 55, no. 3-4, pp. 129-136.

Ahrazem, O., Ibanez, M.D., Lopez-Torrejon, G., Sanchez-Monge, R., Sastre, J., Lombardero, M., Barber, D. \& Salcedo, G. 2005, "Lipid transfer proteins and allergy to oranges", International archives of allergy and immunology, vol. 137, no. 3, pp. 201-210.

Alonso, J.M., Stepanova, A.N., Leisse, T.J., Kim, C.J., Chen, H., Shinn, P., Stevenson, D.K., Zimmerman, J., Barajas, P., Cheuk, R., Gadrinab, C., Heller, C., Jeske, A., Koesema, E., Meyers, C.C., Parker, H., Prednis, L., Ansari, Y., Choy, N., Deen, H., Geralt, M., Hazari, N., Hom, E., Karnes, M., Mulholland, C., Ndubaku, R., Schmidt, I., Guzman, P., Aguilar-Henonin, L., Schmid, M., Weigel, D., Carter, D.E., Marchand, T., Risseeuw, E., Brogden, D., Zeko, A., Crosby, W.L., Berry, C.C. \& Ecker, J.R. 2003, "Genome-wide insertional mutagenesis of Arabidopsis thaliana", Science (New York, N.Y.), vol. 301, no. 5633, pp. 653-657.

Altschul, S.F., Gish, W., Miller, W., Myers, E.W. \& Lipman, D.J. 1990, "Basic local alignment search tool", Journal of Molecular Biology, vol. 215, no. 3, pp. 403-410.

Arabidopsis Genome Initiative 2000, "Analysis of the genome sequence of the flowering plant Arabidopsis thaliana", Nature, vol. 408, no. 6814, pp. 796-815.

Arondel, V. \& Kader, J.C. 1990, "Lipid transfer in plants", Experientia, vol. 46, no. 6, pp. 579-585.

Arondel, V., Vergnolle, C., Tchang, F. \& Kader, J.C. 1990, "Bifunctional lipid-transfer: fatty acidbinding proteins in plants", Molecular and cellular biochemistry, vol. 98, no. 1-2, pp. 49-56.

Asero, R., Mistrello, G., Roncarolo, D., de Vries, S.C., Gautier, M.F., Ciurana, C.L., Verbeek, E., Mohammadi, T., Knul-Brettlova, V., Akkerdaas, J.H., Bulder, I., Aalberse, R.C. \& van Ree, R. 2000 , "Lipid transfer protein: a pan-allergen in plant-derived foods that is highly resistant to pepsin digestion", International archives of allergy and immunology, vol. 122, no. 1, pp. 20-32.

Berardini, T.Z., Mundodi, S., Reiser, L., Huala, E., Garcia-Hernandez, M., Zhang, P., Mueller, L.A., Yoon, J., Doyle, A., Lander, G., Moseyko, N., Yoo, D., Xu, I., Zoeckler, B., Montoya, M., Miller, N., Weems, D. \& Rhee, S.Y. 2004, "Functional annotation of the Arabidopsis genome using controlled vocabularies", Plant Physiology, vol. 135, no. 2, pp. 745-755.

Bernhard, W.R. \& Somerville, C.R. 1989, "Coidentity of putative amylase inhibitors from barley and finger millet with phospholipid transfer proteins inferred from amino acid sequence homology", Archives of Biochemistry and Biophysics, vol. 269, no. 2, pp. 695-697.

Bernhard, W.R., Thoma, S., Botella, J. \& Somerville, C.R. 1991, "Isolation of a cDNA Clone for Spinach Lipid Transfer Protein and Evidence that the Protein Is Synthesized by the Secretory Pathway", Plant Physiology, vol. 95, no. 1, pp. 164-170.

Beyer, C.F., Craig, L.C. \& Gibbons, W.A. 1973, "Structural requirements for binding and fluorescence enhancement of the fluorescent probe TNS with peptides", Nature: New biology, vol. 241, no. 107, pp. 78-80.

Bird, D., Beisson, F., Brigham, A., Shin, J., Greer, S., Jetter, R., Kunst, L., Wu, X., Yephremov, A. \& Samuels, L. 2007, "Characterization of Arabidopsis ABCG11/WBC11, an ATP binding cassette $(\mathrm{ABC})$ transporter that is required for cuticular lipid secretion", The Plant Journal : for cell and molecular biology, vol. 52, no. 3, pp. 485-498.

Blackmore, S., Wortley, A.H., Skvarla, J.J. \& Rowley, J.R. 2007, "Pollen wall development in flowering plants", The New phytologist, vol. 174, no. 3, pp. 483-498. 
Blilou, I., Ocampo, J.A. \& Garcia-Garrido, J.M. 2000, "Induction of Ltp (lipid transfer protein) and $\mathrm{Pal}$ (phenylalanine ammonia-lyase) gene expression in rice roots colonized by the arbuscular mycorrhizal fungus Glomus mosseae", Journal of experimental botany, vol. 51, no. 353, pp. 1969-1977.

Bloj, B. \& Zilversmit, D.B. 1981, "Lipid transfer proteins in the study of artificial and natural membranes", Molecular and cellular biochemistry, vol. 40, no. 3, pp. 163-172.

Boom, A., Sinninge Damsté, J.S. \& de Leeuw, J.W. 2005, "Cutan, a common aliphatic biopolymer in cuticles of drought-adapted plants", Organic Geochemistry, vol. 36, no. 4, pp. 595-601.

Borner, G.H., Sherrier, D.J., Stevens, T.J., Arkin, I.T. \& Dupree, P. 2002, "Prediction of glycosylphosphatidylinositol-anchored proteins in Arabidopsis. A genomic analysis", Plant Physiology, vol. 129, no. 2, pp. 486-499.

Boutrot, F., Chantret, N. \& Gautier, M.F. 2008, "Genome-wide analysis of the rice and Arabidopsis non-specific lipid transfer protein (nsLtp) gene families and identification of wheat nsLtp genes by EST data mining", BMC genomics, vol. 9, pp. 86.

Boutrot, F., Guirao, A., Alary, R., Joudrier, P. \& Gautier, M.F. 2005, "Wheat non-specific lipid transfer protein genes display a complex pattern of expression in developing seeds", Biochimica et biophysica acta, vol. 1730, no. 2, pp. 114-125.

Boutrot, F., Meynard, D., Guiderdoni, E., Joudrier, P. \& Gautier, M.F. 2007, "The Triticum aestivum non-specific lipid transfer protein (TaLtp) gene family: comparative promoter activity of six TaLtp genes in transgenic rice", Planta, vol. 225, no. 4, pp. 843-862.

Boyer, J.S., Wong, S.C. \& Farquhar, G.D. 1997, "CO2 and Water Vapor Exchange across Leaf Cuticle (Epidermis) at Various Water Potentials", Plant Physiology, vol. 114, no. 1, pp. 185-191.

Brooks, J. \& Shaw, G. 1968, "Chemical structure of the exine of pollen walls and a new function for carotenoids in nature", Nature, vol. 219, no. 5153, pp. 532-533.

Brotman, Y., Lisec, J., Meret, M., Chet, I., Willmitzer, L. \& Viterbo, A. 2012, "Transcript and metabolite analysis of the Trichoderma-induced systemic resistance response to Pseudomonas syringae in Arabidopsis thaliana", Microbiology (Reading, England), vol. 158, no. Pt 1, pp. 139146.

Cameron, K.D., Teece, M.A. \& Smart, L.B. 2006, "Increased accumulation of cuticular wax and expression of lipid transfer protein in response to periodic drying events in leaves of tree tobacco", Plant Physiology, vol. 140, no. 1, pp. 176-183.

Canevascini, S., Caderas, D., Mandel, T., Fleming, A.J., Dupuis, I. \& Kuhlemeier, C. 1996, "Tissuespecific expression and promoter analysis of the tobacco Itp1 gene", Plant Physiology, vol. 112, no. 2, pp. 513-524.

Caplan, A., Herrera-Estrella, L., Inze, D., Van Haute, E., Van Montagu, M., Schell, J. \& Zambryski, P. 1983, "Introduction of genetic material into plant cells", Science (New York, N.Y.), vol. 222, no. 4625, pp. 815-821.

Castagnaro, A. \& Garcia-Olmedo, F. 1994, "A fatty-acid-binding protein from wheat kernels", FEBS letters, vol. 349, no. 1, pp. 117-119.

Castro, M.S., Gerhardt, I.R., Orru, S., Pucci, P. \& Bloch, C.,Jr 2003, "Purification and characterization of a small $(7.3 \mathrm{kDa})$ putative lipid transfer protein from maize seeds", Journal of chromatography.B, Analytical technologies in the biomedical and life sciences, vol. 794, no. 1, pp. 109-114.

Charvolin, D., Douliez, J.P., Marion, D., Cohen-Addad, C. \& Pebay-Peyroula, E. 1999, "The crystal structure of a wheat nonspecific lipid transfer protein (ns-LTP1) complexed with two molecules of phospholipid at 2.1 A resolution", European journal of biochemistry / FEBS, vol. 264, no. 2, pp. 562-568. 
Chen, C., Chen, G., Hao, X., Cao, B., Chen, Q., Liu, S. \& Lei, J. 2011, "CaMF2, an anther-specific lipid transfer protein (LTP) gene, affects pollen development in Capsicum annuum L", Plant science : an international journal of experimental plant biology, vol. 181, no. 4, pp. 439-448.

Chen, C., Chen, G., Hao, X., Cao, B., Chen, Q., Liu, S. \& Lei, J. 2011, "CaMF2, an anther-specific lipid transfer protein (LTP) gene, affects pollen development in Capsicum annuum L", Plant science : an international journal of experimental plant biology, vol. 181, no. 4, pp. 439-448.

Chen, C., Chen, G., Hao, X., Cao, B., Chen, Q., Liu, S. \& Lei, J. 2011, "CaMF2, an anther-specific lipid transfer protein (LTP) gene, affects pollen development in Capsicum annuum L", Plant science : an international journal of experimental plant biology, vol. 181, no. 4, pp. 439-448.

Cheng, C.S., Samuel, D., Liu, Y.J., Shyu, J.C., Lai, S.M., Lin, K.F. \& Lyu, P.C. 2004, "Binding mechanism of nonspecific lipid transfer proteins and their role in plant defense", Biochemistry, vol. 43, no. 43, pp. 13628-13636.

Chesebro, B., Trifilo, M., Race, R., Meade-White, K., Teng, C., LaCasse, R., Raymond, L., Favara, C., Baron, G., Priola, S., Caughey, B., Masliah, E. \& Oldstone, M. 2005, "Anchorless prion protein results in infectious amyloid disease without clinical scrapie", Science (New York, N.Y.), vol. 308, no. 5727, pp. 1435-1439.

Chiang, P.W., Song, W.J., Wu, K.Y., Korenberg, J.R., Fogel, E.J., Van Keuren, M.L., Lashkari, D. \& Kurnit, D.M. 1996, "Use of a fluorescent-PCR reaction to detect genomic sequence copy number and transcriptional abundance", Genome research, vol. 6, no. 10, pp. 1013-1026.

Choi, Y.E., Lim, S., Kim, H.J., Han, J.Y., Lee, M.H., Yang, Y., Kim, J.A. \& Kim, Y.S. 2012, "Tobacco NtLTP1, a glandular-specific lipid transfer protein, is required for lipid secretion from glandular trichomes", The Plant Journal : for cell and molecular biology, vol. 70, no. 3, pp. 480-491.

Chyi, Y., Jorgensen, R., Goldstein, D., Tanksley, S. \& Loaiza-Figueroa, F. 1986, "Locations and stability of Agrobacterium-mediated T-DNA insertions in the Lycopersicon genome", Molecular and General Genetics $M G G$, vol. 204, no. 1, pp. 64-69.

Clark, A.M. \& Bohnert, H.J. 1999, "Cell-specific expression of genes of the lipid transfer protein family from Arabidopsis thaliana", Plant \& Cell Physiology, vol. 40, no. 1, pp. 69-76.

Clarke, J.T., Warnock, R.C. \& Donoghue, P.C. 2011, "Establishing a time-scale for plant evolution", The New phytologist, vol. 192, no. 1, pp. 266-301.

Clough, S.J. \& Bent, A.F. 1998, "Floral dip: a simplified method for Agrobacterium-mediated transformation of Arabidopsis thaliana", The Plant Journal : for cell and molecular biology, vol. 16, no. 6, pp. 735-743.

Cominelli, E., Galbiati, M. \& Tonelli, C. 2008, "Integration of water stress response: Cell expansion and cuticle deposition in Arabidopsis thaliana", Plant signaling \& behavior, vol. 3, no. 8, pp. 556557.

Cook, M.E. \& Graham, L.E. 1998, "Structural Similarities between Surface Layers of Selected Charophycean Algae and Bryophytes and the Cuticles of Vascular Plants", International journal of plant sciences, vol. 159 , no. 5 , pp. 780-787.

Cove, D., Bezanilla, M., Harries, P. \& Quatrano, R. 2006, "Mosses as model systems for the study of metabolism and development", Annual review of plant biology, vol. 57, pp. 497-520.

Cove, D.J., Perroud, P.F., Charron, A.J., McDaniel, S.F., Khandelwal, A. \& Quatrano, R.S. 2009, "Culturing the moss Physcomitrella patens", Cold Spring Harbor protocols, vol. 2009, no. 2, pp. pdb.prot5136.

Dalgliesh, C.E., Horning, E.C., Horning, M.G., Knox, K.L. \& Yarger, K. 1966, "A gas-liquidchromatographic procedure for separating a wide range of metabolites occuring in urine or tissue extracts", The Biochemical journal, vol. 101, no. 3, pp. 792-810. 
Dayhoff, M.O., Schwartz, R.M. \& Orcutt, B.C. 1978, "A model of evolutionary change in proteins", Atlas of protein sequence and structure, vol. 5, no. suppl 3, pp. 345-351.

Debeaujon, I., Leon-Kloosterziel, K.M. \& Koornneef, M. 2000, "Influence of the testa on seed dormancy, germination, and longevity in Arabidopsis", Plant Physiology, vol. 122, no. 2, pp. 403414.

Debono, A., Yeats, T.H., Rose, J.K., Bird, D., Jetter, R., Kunst, L. \& Samuels, L. 2009, "Arabidopsis LTPG is a glycosylphosphatidylinositol-anchored lipid transfer protein required for export of lipids to the plant surface", The Plant Cell, vol. 21, no. 4, pp. 1230-1238.

Demmig-Adams, B. \& Adams, W.W.,3rd 2002, "Antioxidants in photosynthesis and human nutrition", Science (New York, N.Y.), vol. 298, no. 5601, pp. 2149-2153.

DeRisi, J.L., Iyer, V.R. \& Brown, P.O. 1997, "Exploring the metabolic and genetic control of gene expression on a genomic scale", Science (New York, N.Y.), vol. 278, no. 5338, pp. 680-686.

dit Frey, N.F., Muller, P., Jammes, F., Kizis, D., Leung, J., Perrot-Rechenmann, C. \& Bianchi, M.W. 2010, "The RNA binding protein Tudor-SN is essential for stress tolerance and stabilizes levels of stress-responsive mRNAs encoding secreted proteins in Arabidopsis", The Plant Cell, vol. 22, no. 5, pp. 1575-1591.

Domínguez, ,E., Mercado, J.,A., Quesada, M.,A. \& Heredia, A. 1999, "Pollen sporopollenin: degradation and structural elucidation", Sexual Plant Reproduction, vol. 12, no. 3, pp. 171-178

Douliez, J.P., Michon, T. \& Marion, D. 2000, "Steady-state tyrosine fluorescence to study the lipidbinding properties of a wheat non-specific lipid-transfer protein (nsLTP1)", Biochimica et biophysica acta, vol. 1467, no. 1, pp. 65-72.

Edwards, D., Davies, K.,L. \& Axe, L. 1992, "A vascular conducting strand in the early land plant Cooksonia", Nature, vol. 357, pp. 683-685

Edwards, D. 2003, "Xylem in early tracheophytes", Plant, Cell \& Environment, vol. 26, no. 1, pp. 5772.

Egger, M., Hauser, M., Mari, A., Ferreira, F. \& Gadermaier, G. 2010, "The role of lipid transfer proteins in allergic diseases", Current allergy and asthma reports, vol. 10, no. 5, pp. 326-335.

Fahy, E., Subramaniam, S., Brown, H.A., Glass, C.K., Merrill, A.H.,Jr, Murphy, R.C., Raetz, C.R., Russell, D.W., Seyama, Y., Shaw, W., Shimizu, T., Spener, F., van Meer, G., VanNieuwenhze, M.S., White, S.H., Witztum, J.L. \& Dennis, E.A. 2005, "A comprehensive classification system for lipids", Journal of lipid research, vol. 46, no. 5, pp. 839-861.

Fairon-Demaret, M. 1996, "Dorinnotheca streelii Fairon-Demaret, gen. et sp. nov., a new early seed plant from the upper Famennian of Belgium", Review of palaeobotany and palynology, vol. 93, no. 1-4, pp. 217-233.

Felsenstein, J. 1981, "Evolutionary trees from DNA sequences: a maximum likelihood approach", Journal of Molecular Evolution, vol. 17, no. 6, pp. 368-376.

Feng, D.F. \& Doolittle, R.F. 1987, "Progressive sequence alignment as a prerequisite to correct phylogenetic trees", Journal of Molecular Evolution, vol. 25, no. 4, pp. 351-360.

Ferguson, M.A.J., Kinoshita, T. \& Hart, G.W. 2009, "Glycosylphosphatidylinositol Anchors" in Essentials of Glycobiology, eds. A. Varki, R.D. Cummings, J.D. Esko, et al, 2nd edn, The Consortium of Glycobiology Editors, La Jolla, California, Cold Spring Harbor (NY).

Frank, W., Ratnadewi, D. \& Reski, R. 2005, "Physcomitrella patens is highly tolerant against drought, salt and osmotic stress", Planta, vol. 220, no. 3, pp. 384-394.

Franke, R., Briesen, I., Wojciechowski, T., Faust, A., Yephremov, A., Nawrath, C. \& Schreiber, L. 2005, "Apoplastic polyesters in Arabidopsis surface tissues--a typical suberin and a particular cutin", Phytochemistry, vol. 66, no. 22, pp. 2643-2658. 
Gausing, K. 1994, "Lipid transfer protein genes specifically expressed in barley leaves and coleoptiles", Planta, vol. 192, no. 4, pp. 574-580.

Gerrienne, P., Meyer-Berthaud, B., Fairon-Demaret, M., Streel, M. \& Steemans, P. 2004, "Runcaria, a middle devonian seed plant precursor", Science (New York, N.Y.), vol. 306, no. 5697, pp. 856-858.

Gincel, E., Simorre, J.P., Caille, A., Marion, D., Ptak, M. \& Vovelle, F. 1994, "Three-dimensional structure in solution of a wheat lipid-transfer protein from multidimensional $1 \mathrm{H}-\mathrm{NMR}$ data. A new folding for lipid carriers", European journal of biochemistry / FEBS, vol. 226, no. 2, pp. 413-422.

Goda, H., Sasaki, E., Akiyama, K., Maruyama-Nakashita, A., Nakabayashi, K., Li, W., Ogawa, M., Yamauchi, Y., Preston, J., Aoki, K., Kiba, T., Takatsuto, S., Fujioka, S., Asami, T., Nakano, T., Kato, H., Mizuno, T., Sakakibara, H., Yamaguchi, S., Nambara, E., Kamiya, Y., Takahashi, H., Hirai, M.Y., Sakurai, T., Shinozaki, K., Saito, K., Yoshida, S. \& Shimada, Y. 2008, "The AtGenExpress hormone and chemical treatment data set: experimental design, data evaluation, model data analysis and data access", The Plant Journal : for cell and molecular biology, vol. 55, no. 3, pp. 526-542.

Gomar, J., Petit, M.C., Sodano, P., Sy, D., Marion, D., Kader, J.C., Vovelle, F. \& Ptak, M. 1996, "Solution structure and lipid binding of a nonspecific lipid transfer protein extracted from maize seeds", Protein science : a publication of the Protein Society, vol. 5, no. 4, pp. 565-577.

Gonorazky, A.G., Regente, M.C. \& de la Canal, L. 2005, "Stress induction and antimicrobial properties of a lipid transfer protein in germinating sunflower seeds", Journal of Plant Physiology, vol. 162 , no. 6, pp. 618-624.

Greenfield, N.J. 2006, "Using circular dichroism spectra to estimate protein secondary structure", Nature protocols, vol. 1, no. 6, pp. 2876-2890.

Han, G.W., Lee, J.Y., Song, H.K., Chang, C., Min, K., Moon, J., Shin, D.H., Kopka, M.L., Sawaya, M.R., Yuan, H.S., Kim, T.D., Choe, J., Lim, D., Moon, H.J. \& Suh, S.W. 2001, "Structural basis of non-specific lipid binding in maize lipid-transfer protein complexes revealed by highresolution X-ray crystallography", Journal of Molecular Biology, vol. 308, no. 2, pp. 263-278.

Hayes, T.L. \& Pease, R.F. 1968, "The scanning electron microscope: principles and applications in biology and medicine", Advances in Biological and Medical Physics, vol. 12, pp. 85-137.

Henikoff, S. \& Henikoff, J.G. 1992, "Amino acid substitution matrices from protein blocks", Proceedings of the National Academy of Sciences of the United States of America, vol. 89, no. 22, pp. 10915-10919.

Higgins, D.G. \& Sharp, P.M. 1988, "CLUSTAL: a package for performing multiple sequence alignment on a microcomputer", Gene, vol. 73, no. 1, pp. 237-244.

Holk, R.U.P.a. \& Scherer, G.F.E. 1998, "Fatty acids and lysophospholipids as potential second messengers in auxin action. Rapid activation of phospholipase A2 activity by auxin in suspension-cultured parsley and soybean cells", The Plant Journal, vol. 16, no. 5, pp. 601-611.

Ikezawa, H. 2002, "Glycosylphosphatidylinositol (GPI)-anchored proteins", Biological \& pharmaceutical bulletin, vol. 25, no. 4, pp. 409-417.

James, A.T. \& Martin, A.J. 1951, "Liquid-gas partition chromatography", The Biochemical journal, vol. 48, no. 1, pp. vii.

Jang, C.S., Yim, W.C., Moon, J.C., Hung, J.H., Lee, T.G., Lim, S.D., Cho, S.H., Lee, K.K., Kim, W., Seo, Y.W. \& Lee, B.M. 2008, "Evolution of non-specific lipid transfer protein (nsLTP) genes in the Poaceae family: their duplication and diversity", Molecular genetics and genomics : MGG, vol. 279, no. 5, pp. 481-497.

Jenks, M.A., Joly, R.J., Peters, P.J., Rich, P.J., Axtell, J.D. \& Ashworth, E.N. 1994, "Chemically Induced Cuticle Mutation Affecting Epidermal Conductance to Water Vapor and Disease Susceptibility in Sorghum bicolor (L.) Moench", Plant Physiology, vol. 105, no. 4, pp. 1239-1245. 
Jiang, H., Song, W., Li, A., Yang, X. \& Sun, D. 2011, "Identification of genes differentially expressed in cauliflower associated with resistance to Xanthomonas campestris pv. campestris", Molecular biology reports, vol. 38, no. 1, pp. 621-629.

Jose-Estanyol, M., Gomis-Ruth, F.X. \& Puigdomenech, P. 2004, "The eight-cysteine motif, a versatile structure in plant proteins", Plant Physiology and Biochemistry : PPB / Societe francaise de physiologie vegetale, vol. 42 , no. 5, pp. 355-365.

Kader, J.C. 1975, "Proteins and the intracellular exchange of lipids. I. Stimulation of phospholipid exchange between mitochondria and microsomal fractions by proteins isolated from potato tuber", Biochimica et biophysica acta, vol. 380, no. 1, pp. 31-44.

Kader, J.C., Julienne, M. \& Vergnolle, C. 1984, "Purification and characterization of a spinach-leaf protein capable of transferring phospholipids from liposomes to mitochondria or chloroplasts", European journal of biochemistry / FEBS, vol. 139, no. 2, pp. 411-416.

Kalla, R., Shimamoto, K., Potter, R., Nielsen, P.S., Linnestad, C. \& Olsen, O.A. 1994, "The promoter of the barley aleurone-specific gene encoding a putative $7 \mathrm{kDa}$ lipid transfer protein confers aleurone cell-specific expression in transgenic rice", The Plant Journal : for cell and molecular biology, vol. 6, no. 6, pp. 849-860.

Karol, K.G., McCourt, R.M., Cimino, M.T. \& Delwiche, C.F. 2001, "The closest living relatives of land plants", Science (New York, N.Y.), vol. 294, no. 5550, pp. 2351-2353.

Kenrick, ,Paul \& Crane, P.,R. 1997a, "The origin and early evolution of plants on land", Nature, vol. 389, pp. 33-39.

Kenrick, ,Paul \& Crane, P.,R. 1997b, "The origin and early diversification of land plants - A cladistic study", Smithsonian Series in Comparative Evolutionary Biology (Smithsonian Institution Press, Washington, DC, 1997.

Kilian, J., Whitehead, D., Horak, J., Wanke, D., Weinl, S., Batistic, O., D'Angelo, C., Bornberg-Bauer, E., Kudla, J. \& Harter, K. 2007, "The AtGenExpress global stress expression data set: protocols, evaluation and model data analysis of UV-B light, drought and cold stress responses", The Plant Journal : for cell and molecular biology, vol. 50, no. 2, pp. 347-363.

Kim, H., Lee, S.B., Kim, H.J., Min, M.K., Hwang, I. \& Suh, M.C. 2012, "Characterization of glycosylphosphatidylinositol-anchored lipid transfer protein 2 (LTPG2) and overlapping function between LTPG/LTPG1 and LTPG2 in cuticular wax export or accumulation in Arabidopsis thaliana", Plant \& Cell Physiology, vol. 53, no. 8, pp. 1391-1403.

Kirubakaran, S.I., Begum, S.M., Ulaganathan, K. \& Sakthivel, N. 2008, "Characterization of a new antifungal lipid transfer protein from wheat", Plant Physiology and Biochemistry: PPB / Societe francaise de physiologie vegetale, vol. 46, no. 10, pp. 918-927.

Kolattukudy, P.E. 2001, "Polyesters in higher plants", Advances in Biochemical Engineering/Biotechnology, vol. 71, pp. 1-49.

Kolattukudy, P.E. 1980, "Biopolyester membranes of plants: cutin and suberin", Science (New York, N.Y.), vol. 208, no. 4447, pp. 990-1000.

Kosma, D.K., Bourdenx, B., Bernard, A., Parsons, E.P., Lu, S., Joubes, J. \& Jenks, M.A. 2009, "The impact of water deficiency on leaf cuticle lipids of Arabidopsis", Plant Physiology, vol. 151, no. 4, pp. 1918-1929.

Kotilainen, M., Helariutta, Y., Elomaa, P., Paulin, L. \& Teeri, T.H. 1994, "A corolla- and carpelabundant, non-specific lipid transfer protein gene is expressed in the epidermis and parenchyma of Gerbera hybrida var. Regina (Compositae)", Plant Molecular Biology, vol. 26, no. 3, pp. 971978.

Kovalchuk, N., Smith, J., Bazanova, N., Pyvovarenko, T., Singh, R., Shirley, N., Ismagul, A., Johnson, A., Milligan, A.S., Hrmova, M., Langridge, P. \& Lopato, S. 2012, "Characterization of the wheat 
gene encoding a grain-specific lipid transfer protein TdPR61, and promoter activity in wheat, barley and rice", Journal of experimental botany, vol. 63, no. 5, pp. 2025-2040.

Kovaleva, V., Kiyamova, R., Cramer, R., Krynytskyy, H., Gout, I., Filonenko, V. \& Gout, R. 2009, "Purification and molecular cloning of antimicrobial peptides from Scots pine seedlings", Peptides, vol. 30, no. 12, pp. 2136-2143.

Krause, A., Sigrist, C.J., Dehning, I., Sommer, H. \& Broughton, W.J. 1994, "Accumulation of transcripts encoding a lipid transfer-like protein during deformation of nodulation-competent Vigna unguiculata root hairs", Molecular plant-microbe interactions : MPMI, vol. 7, no. 3, pp. 411-418.

Kreis, M., Forde, B.G., Rahman, S., Miflin, B.J. \& Shewry, P.R. 1985, "Molecular evolution of the seed storage proteins of barley, rye and wheat", Journal of Molecular Biology, vol. 183, no. 3, pp. 499-502.

Kunst, L. \& Samuels, A.L. 2003, "Biosynthesis and secretion of plant cuticular wax", Progress in lipid research, vol. 42, no. 1, pp. 51-80.

Kuromori, T., Ito, T., Sugimoto, E. \& Shinozaki, K. 2011, "Arabidopsis mutant of AtABCG26, an ABC transporter gene, is defective in pollen maturation", Journal of Plant Physiology, vol. 168, no. 16 , pp. 2001-2005.

Kuzuyama, T. \& Seto, H. 2003, "Diversity of the biosynthesis of the isoprene units", Natural product reports, vol. 20, no. 2, pp. 171-183.

Lakhan, S.E., Sabharanjak, S. \& De, A. 2009, "Endocytosis of glycosylphosphatidylinositol-anchored proteins", Journal of Biomedical Science, vol. 16, pp. 93-0127-16-93.

Lang, D., Eisinger, J., Reski, R. \& Rensing, S.A. 2005, "Representation and high-quality annotation of the Physcomitrella patens transcriptome demonstrates a high proportion of proteins involved in metabolism in mosses", Plant biology (Stuttgart, Germany), vol. 7, no. 3, pp. 238-250.

Lascombe, M.B., Bakan, B., Buhot, N., Marion, D., Blein, J.P., Larue, V., Lamb, C. \& Prange, T. 2008, "The structure of "defective in induced resistance" protein of Arabidopsis thaliana, DIR1, reveals a new type of lipid transfer protein", Protein science : a publication of the Protein Society, vol. 17, no. 9 , pp. 1522-1530.

Le, L.Q., Lorenz, Y., Scheurer, S., Fotisch, K., Enrique, E., Bartra, J., Biemelt, S., Vieths, S. \& Sonnewald, U. 2006, "Design of tomato fruits with reduced allergenicity by dsRNAi-mediated inhibition of ns-LTP (Lyc e 3) expression", Plant biotechnology journal, vol. 4, no. 2, pp. 231242.

Lee, J.Y., Min, K., Cha, H., Shin, D.H., Hwang, K.Y. \& Suh, S.W. 1998, "Rice non-specific lipid transfer protein: the 1.6 A crystal structure in the unliganded state reveals a small hydrophobic cavity", Journal of Molecular Biology, vol. 276, no. 2, pp. 437-448.

Lee, S.B., Go, Y.S., Bae, H.J., Park, J.H., Cho, S.H., Cho, H.J., Lee, D.S., Park, O.K., Hwang, I. \& Suh, M.C. 2009, "Disruption of glycosylphosphatidylinositol-anchored lipid transfer protein gene altered cuticular lipid composition, increased plastoglobules, and enhanced susceptibility to infection by the fungal pathogen Alternaria brassicicola", Plant Physiology, vol. 150, no. 1, pp. $42-54$.

Lesk, A.M., Levitt, M. \& Chothia, C. 1986, "Alignment of the amino acid sequences of distantly related proteins using variable gap penalties", Protein engineering, vol. 1, no. 1, pp. 77-78.

Lindorff-Larsen, K. \& Winther, J.R. 2001, "Surprisingly high stability of barley lipid transfer protein, LTP1, towards denaturant, heat and proteases", FEBS letters, vol. 488, no. 3, pp. 145-148.

Liu, K.H. \& Lin, T.Y. 2003, "Cloning and characterization of two novel lipid transfer protein I genes in Vigna radiata", DNA sequence : the journal of DNA sequencing and mapping, vol. 14, no. 6, pp. 420-426. 
Liu, Y.J., Samuel, D., Lin, C.H. \& Lyu, P.C. 2002, "Purification and characterization of a novel 7-kDa non-specific lipid transfer protein-2 from rice (Oryza sativa)", Biochemical and biophysical research communications, vol. 294, no. 3, pp. 535-540.

Lloyd, A.M., Barnason, A.R., Rogers, S.G., Byrne, M.C., Fraley, R.T. \& Horsch, R.B. 1986, "Transformation of Arabidopsis thaliana with Agrobacterium tumefaciens", Science (New York, N.Y.), vol. 234, no. 4775, pp. 464-466.

Loewus, F.A., Baldi, B.G., Franceschi, V.R., Meinert, L.D. \& McCollum, J.J. 1985, "Pollen sporoplasts: dissolution of pollen walls", Plant Physiology, vol. 78, no. 3, pp. 652-654.

Luo, B., Xue, X.Y., Hu, W.L., Wang, L.J. \& Chen, X.Y. 2007, "An ABC transporter gene of Arabidopsis thaliana, AtWBC11, is involved in cuticle development and prevention of organ fusion", Plant \& Cell Physiology, vol. 48, no. 12, pp. 1790-1802.

Lynch, D.V. \& Dunn, T.M. 2004, "An introduction to plant sphingolipids and a review of recent advances in understanding their metabolism and function", New Phytologist, vol. 161, no. 3, pp. 677-702.

Ma, D.P., Liu, H.C., Tan, H., Creech, R.G., Jenkins, J.N. \& Chang, Y.F. 1997, "Cloning and characterization of a cotton lipid transfer protein gene specifically expressed in fiber cells", Biochimica et biophysica acta, vol. 1344, no. 2, pp. 111-114.

Ma, H. 2005, "Molecular genetic analyses of microsporogenesis and microgametogenesis in flowering plants", Annual review of plant biology, vol. 56, pp. 393-434.

Magallon, S., Hilu, K.W. \& Quandt, D. 2013, "Land plant evolutionary timeline: gene effects are secondary to fossil constraints in relaxed clock estimation of age and substitution rates", American Journal of Botany, vol. 100, no. 3, pp. 556-573.

Maldonado, A.M., Doerner, P., Dixon, R.A., Lamb, C.J. \& Cameron, R.K. 2002, "A putative lipid transfer protein involved in systemic resistance signalling in Arabidopsis", Nature, vol. 419, no. 6905, pp. 399-403.

Margulis, L. 1971, "Symbiosis and evolution", Scientific American, vol. 225, no. 2, pp. 48-57.

Mayor, S. \& Riezman, H. 2004, "Sorting GPI-anchored proteins", Nature reviews.Molecular cell biology, vol. 5, no. 2, pp. 110-120.

Meinke, D.W., Cherry, J.M., Dean, C., Rounsley, S.D. \& Koornneef, M. 1998, "Arabidopsis thaliana: a model plant for genome analysis", Science (New York, N.Y.), vol. 282, no. 5389, pp. 662, 679-82.

Meyerowitz, E.M. \& Somerville, C.R. 1994, Arabidopsis, Cold Spring Harbor Laboratory Press, Plainview , N.Y.

Mitton, F.M., Pinedo, M.L. \& de la Canal, L. 2009, "Phloem sap of tomato plants contains a DIR1 putative ortholog", Journal of Plant Physiology, vol. 166, no. 5, pp. 543-547.

Molina, A., Segura, A. \& Garcia-Olmedo, F. 1993, "Lipid transfer proteins (nsLTPs) from barley and maize leaves are potent inhibitors of bacterial and fungal plant pathogens", FEBS letters, vol. 316, no. 2, pp. 119-122.

Molina, I., Bonaventure, G., Ohlrogge, J. \& Pollard, M. 2006, "The lipid polyester composition of Arabidopsis thaliana and Brassica napus seeds", Phytochemistry, vol. 67, no. 23, pp. 2597-2610.

Moreau, R.A. \& Huang, A.H. 1977, "Gluconeogenesis from storage wax in the cotyledons of jojoba seedlings", Plant Physiology, vol. 60, no. 2, pp. 329-333.

Muller, A., Kloppel, C., Smith-Valentine, M., Van Houten, J. \& Simon, M. 2012, "Selective and programmed cleavage of GPI-anchored proteins from the surface membrane by phospholipase C", Biochimica et biophysica acta, vol. 1818, no. 1, pp. 117-124.

Munnik, T. 2001, "Phosphatidic acid: an emerging plant lipid second messenger", Trends in plant science, vol. 6 , no. 5, pp. 227-233. 
Murphy, D.J. 1993, "Structure, function and biogenesis of storage lipid bodies and oleosins in plants", Progress in lipid research, vol. 32, no. 3, pp. 247-280.

Nielsen, K.K., Nielsen, J.E., Madrid, S.M. \& Mikkelsen, J.D. 1996, "New antifungal proteins from sugar beet (Beta vulgaris L.) showing homology to non-specific lipid transfer proteins", Plant Molecular Biology, vol. 31, no. 3, pp. 539-552.

Nieuwland, J., Feron, R., Huisman, B.A., Fasolino, A., Hilbers, C.W., Derksen, J. \& Mariani, C. 2005, "Lipid transfer proteins enhance cell wall extension in tobacco", The Plant Cell, vol. 17, no. 7, pp. 2009-2019.

Nishimura, S., Tatano, S., Gomi, K., Ohtani, K., Fukumoto, T. \& Akimitsu, K. 2008, "Chloroplastlocalized nonspecific lipid transfer protein with anti-fungal activity from rough lemon", Physiological and Molecular Plant Pathology, vol. 72, no. 4-6, pp. 134-140.

Oloriz, M.I., Gil, V., Rojas, L., Portal, O., Izquierdo, Y., Jimenez, E. \& Hofte, M. 2012, "Sugarcane genes differentially expressed in response to Puccinia melanocephala infection: identification and transcript profiling", Plant Cell Reports, vol. 31, no. 5, pp. 955-969.

Ooi, L.S., Tian, L., Su, M., Ho, W.S., Sun, S.S., Chung, H.Y., Wong, H.N. \& Ooi, V.E. 2008, "Isolation, characterization, molecular cloning and modeling of a new lipid transfer protein with antiviral and antiproliferative activities from Narcissus tazetta", Peptides, vol. 29, no. 12, pp. 2101-2109.

Ossendorp, B.C., Geijtenbeek, T.B. \& Wirtz, K.W. 1992, "The precursor form of the rat liver nonspecific lipid-transfer protein, expressed in Escherichia coli, has lipid transfer activity", FEBS letters, vol. 296, no. 2, pp. 179-183.

Ostergaard, J., Vergnolle, C., Schoentgen, F. \& Kader, J.C. 1993, "Acyl-binding/lipid-transfer proteins from rape seedlings, a novel category of proteins interacting with lipids", Biochimica et biophysica acta, vol. 1170, no. 2, pp. 109-117.

Ostergaard, J., Vergnolle, C., Schoentgen, F. \& Kader, J.C. 1993, "Acyl-binding/lipid-transfer proteins from rape seedlings, a novel category of proteins interacting with lipids", Biochimica et biophysica acta, vol. 1170, no. 2, pp. 109-117.

Pagnussat, L., Burbach, C., Baluska, F. \& de la Canal, L. 2012, "An extracellular lipid transfer protein is relocalized intracellularly during seed germination", Journal of experimental botany, vol. 63, no. 18 , pp. 6555-6563.

Palacin, A., Cumplido, J., Figueroa, J., Ahrazem, O., Sanchez-Monge, R., Carrillo, T., Salcedo, G. \& Blanco, C. 2006, "Cabbage lipid transfer protein Bra o 3 is a major allergen responsible for crossreactivity between plant foods and pollens", The Journal of allergy and clinical immunology, vol. 117 , no. 6, pp. 1423-1429.

Park, C.J., Shin, R., Park, J.M., Lee, G.J., You, J.S. \& Paek, K.H. 2002, "Induction of pepper cDNA encoding a lipid transfer protein during the resistance response to tobacco mosaic virus", Plant Molecular Biology, vol. 48, no. 3, pp. 243-254.

Park, S.Y., Jauh, G.Y., Mollet, J.C., Eckard, K.J., Nothnagel, E.A., Walling, L.L. \& Lord, E.M. 2000, "A lipid transfer-like protein is necessary for lily pollen tube adhesion to an in vitro stylar matrix", The Plant Cell, vol. 12, no. 1, pp. 151-164.

Park, S.Y. \& Lord, E.M. 2003, "Expression studies of SCA in lily and confirmation of its role in pollen tube adhesion", Plant Molecular Biology, vol. 51, no. 2, pp. 183-189.

Pasquato, N., Berni, R., Folli, C., Folloni, S., Cianci, M., Pantano, S., Helliwell, J.R. \& Zanotti, G. 2006, "Crystal structure of peach Pru p 3, the prototypic member of the family of plant nonspecific lipid transfer protein pan-allergens", Journal of Molecular Biology, vol. 356, no. 3, pp. 684-694.

Pasquato, N., Berni, R., Folli, C., Folloni, S., Cianci, M., Pantano, S., Helliwell, J.R. \& Zanotti, G. 2006, "Crystal structure of peach Pru p 3, the prototypic member of the family of plant non- 
specific lipid transfer protein pan-allergens", Journal of Molecular Biology, vol. 356, no. 3, pp. 684-694.

Pastorello, E.A., Pravettoni, V., Farioli, L., Ispano, M., Fortunato, D., Monza, M., Giuffrida, M.G., Rivolta, F., Scibola, E., Ansaloni, R., Incorvaia, C., Conti, A. \& Ortolani, C. 1999, "Clinical role of a lipid transfer protein that acts as a new apple-specific allergen", The Journal of allergy and clinical immunology, vol. 104, no. 5, pp. 1099-1106.

Pastorello, E.A., Vieths, S., Pravettoni, V., Farioli, L., Trambaioli, C., Fortunato, D., Luttkopf, D., Calamari, M., Ansaloni, R., Scibilia, J., Ballmer-Weber, B.K., Poulsen, L.K., Wutrich, B., Hansen, K.S., Robino, A.M., Ortolani, C. \& Conti, A. 2002, "Identification of hazelnut major allergens in sensitive patients with positive double-blind, placebo-controlled food challenge results", The Journal of allergy and clinical immunology, vol. 109, no. 3, pp. 563-570.

Paulick, M.G. \& Bertozzi, C.R. 2008, "The glycosylphosphatidylinositol anchor: a complex membrane-anchoring structure for proteins", Biochemistry, vol. 47, no. 27, pp. 6991-7000.

Petti, C., Khan, M. \& Doohan, F. 2010, "Lipid transfer proteins and protease inhibitors as key factors in the priming of barley responses to Fusarium head blight disease by a biocontrol strain of Pseudomonas fluorescens", Functional \& integrative genomics, vol. 10, no. 4, pp. 619-627.

Pighin, J.A., Zheng, H., Balakshin, L.J., Goodman, I.P., Western, T.L., Jetter, R., Kunst, L. \& Samuels, A.L. 2004, "Plant cuticular lipid export requires an ABC transporter", Science (New York, N.Y.), vol. 306, no. 5696, pp. 702-704.

Pii, Y., Astegno, A., Peroni, E., Zaccardelli, M., Pandolfini, T. \& Crimi, M. 2009, "The Medicago truncatula N5 gene encoding a root-specific lipid transfer protein is required for the symbiotic interaction with Sinorhizobium meliloti", Molecular plant-microbe interactions : MPMI, vol. 22, no. 12 , pp. $1577-1587$.

Pollard, M., Beisson, F., Li, Y. \& Ohlrogge, J.B. 2008, "Building lipid barriers: biosynthesis of cutin and suberin", Trends in plant science, vol. 13, no. 5, pp. 236-246.

Porter, R.H., Durrell, M. \& Romm, H.J. 1947, "The Use of 2,3,5-Triphenyl-Tetrazoliumchloride as a Measure of Seed Germinability", Plant Physiology, vol. 22, no. 2, pp. 149-159.

Poznanski, J., Sodano, P., Suh, S.W., Lee, J.Y., Ptak, M. \& Vovelle, F. 1999, "Solution structure of a lipid transfer protein extracted from rice seeds. Comparison with homologous proteins", European journal of biochemistry / FEBS, vol. 259, no. 3, pp. 692-708.

Pruitt, R.E. \& Meyerowitz, E.M. 1986, "Characterization of the genome of Arabidopsis thaliana", Journal of Molecular Biology, vol. 187, no. 2, pp. 169-183.

Pyee, J., Yu, H. \& Kolattukudy, P.E. 1994, "Identification of a lipid transfer protein as the major protein in the surface wax of broccoli (Brassica oleracea) leaves", Archives of Biochemistry and Biophysics, vol. 311, no. 2, pp. 460-468.

Quilichini, T.D., Friedmann, M.C., Samuels, A.L. \& Douglas, C.J. 2010, "ATP-binding cassette transporter G26 is required for male fertility and pollen exine formation in Arabidopsis", Plant Physiology, vol. 154, no. 2, pp. 678-690.

Rege, T.A. \& Hagood, J.S. 2006, "Thy-1 as a regulator of cell-cell and cell-matrix interactions in axon regeneration, apoptosis, adhesion, migration, cancer, and fibrosis", FASEB journal : official publication of the Federation of American Societies for Experimental Biology, vol. 20, no. 8, pp. 1045-1054.

Reinbothe, C., Springer, A., Samol, I. \& Reinbothe, S. 2009, "Plant oxylipins: role of jasmonic acid during programmed cell death, defence and leaf senescence", The FEBS journal, vol. 276, no. 17, pp. 4666-4681.

Rensing, S.A., Fritzowsky, D., Lang, D. \& Reski, R. 2005, "Protein encoding genes in an ancient plant: analysis of codon usage, retained genes and splice sites in a moss, Physcomitrella patens", BMC genomics, vol. 6, pp. 43. 
Rep, M., Dekker, H.L., Vossen, J.H., de Boer, A.D., Houterman, P.M., de Koster, C.G. \& Cornelissen, B.J. 2003, "A tomato xylem sap protein represents a new family of small cysteine-rich proteins with structural similarity to lipid transfer proteins", FEBS letters, vol. 534, no. 1-3, pp. 82-86.

Reski, R. 1998, "DEVELOPMENT, GENETICS AND MOLECULAR BIOLOGY OF MOSSES", Botanica acta, vol. 111, no. 11, pp. 1-15.

Rhee, S.Y., Beavis, W., Berardini, T.Z., Chen, G., Dixon, D., Doyle, A., Garcia-Hernandez, M., Huala, E., Lander, G., Montoya, M., Miller, N., Mueller, L.A., Mundodi, S., Reiser, L., Tacklind, J., Weems, D.C., Wu, Y., Xu, I., Yoo, D., Yoon, J. \& Zhang, P. 2003, "The Arabidopsis Information Resource (TAIR): a model organism database providing a centralized, curated gateway to Arabidopsis biology, research materials and community", Nucleic acids research, vol. 31, no. 1, pp. 224-228.

Robinson, J.A. 1991, "Polyketide synthase complexes: their structure and function in antibiotic biosynthesis", Philosophical transactions of the Royal Society of London.Series B, Biological sciences, vol. 332, no. 1263, pp. 107-114.

Rozema, J., van de Staaij, J., Bjorn, L.O. \& Caldwell, M. 1997, "UV-B as an environmental factor in plant life: stress and regulation", Trends in ecology \& evolution, vol. 12, no. 1, pp. 22-28.

Sabharanjak, S., Sharma, P., Parton, R.G. \& Mayor, S. 2002, "GPI-anchored proteins are delivered to recycling endosomes via a distinct cdc42-regulated, clathrin-independent pinocytic pathway", Developmental cell, vol. 2, no. 4, pp. 411-423.

Saiki, R.K., Gelfand, D.H., Stoffel, S., Scharf, S.J., Higuchi, R., Horn, G.T., Mullis, K.B. \& Erlich, H.A. 1988, "Primer-directed enzymatic amplification of DNA with a thermostable DNA polymerase", Science (New York, N.Y.), vol. 239, no. 4839, pp. 487-491.

Saitou, N. \& Nei, M. 1987, "The neighbor-joining method: a new method for reconstructing phylogenetic trees", Molecular biology and evolution, vol. 4, no. 4, pp. 406-425.

Sakurai, T., Satou, M., Akiyama, K., Iida, K., Seki, M., Kuromori, T., Ito, T., Konagaya, A., Toyoda, T. \& Shinozaki, K. 2005, "RARGE: a large-scale database of RIKEN Arabidopsis resources ranging from transcriptome to phenome", Nucleic acids research, vol. 33, no. Database issue, pp. D64750 .

Samuel, D., Liu, Y.J., Cheng, C.S. \& Lyu, P.C. 2002, "Solution structure of plant nonspecific lipid transfer protein-2 from rice (Oryza sativa)", The Journal of biological chemistry, vol. 277, no. 38, pp. 35267-35273.

Samuels, L., Kunst, L. \& Jetter, R. 2008, "Sealing plant surfaces: cuticular wax formation by epidermal cells", Annual review of plant biology, vol. 59, pp. 683-707.

Sanchez-Monge, R., Lombardero, M., Garcia-Selles, F.J., Barber, D. \& Salcedo, G. 1999, "Lipidtransfer proteins are relevant allergens in fruit allergy", The Journal of allergy and clinical immunology, vol. 103, no. 3 Pt 1, pp. 514-519.

Sawano, Y., Hatano, K., Miyakawa, T., Komagata, H., Miyauchi, Y., Yamazaki, H. \& Tanokura, M. 2008, "Proteinase inhibitor from ginkgo seeds is a member of the plant nonspecific lipid transfer protein gene family", Plant Physiology, vol. 146, no. 4, pp. 1909-1919.

Schaefer, D.G. 2002, "A new moss genetics: targeted mutagenesis in Physcomitrella patens", Annual review of plant biology, vol. 53, pp. 477-501.

Schaefer, D.G. 2001, "Gene targeting in Physcomitrella patens", Current opinion in plant biology, vol. 4, no. 2, pp. 143-150.

Schaefer, D.G. \& Zryd, J.P. 2001, "The moss Physcomitrella patens, now and then", Plant Physiology, vol. 127 , no. 4, pp. 1430-1438. 
Schmid, M., Davison, T.S., Henz, S.R., Pape, U.J., Demar, M., Vingron, M., Scholkopf, B., Weigel, D. \& Lohmann, J.U. 2005, "A gene expression map of Arabidopsis thaliana development", Nature genetics, vol. 37, no. 5, pp. 501-506.

Schreiber, L., Franke, R., \& Hartmann, K. 2005, "Effects of NO 3 deficiency and NaCl stress on suberin deposition in rhizo- and hypodermal (RHCW) and endodermal cell walls (ECW) of castor bean (Ricinus communis L.) roots", Plant and Soil, vol. 269, no. 1-2, pp. 333-339

Schreiber, L. 2010, "Transport barriers made of cutin, suberin and associated waxes", Trends in plant science, vol. 15 , no. 10 , pp. 546-553.

Schween, G., Hohe, A., Koprivova, A. \& Reski, R. 2003, "Effects of nutrients, cell density and culture techniques on protoplast regeneration and early protonema development in a moss, Physcomitrella patens", Journal of Plant Physiology, vol. 160, no. 2, pp. 209-212.

Scotland, R.,W. \& Wortley, A.,H. 2003, "How Many Species of Seed Plants Are There?", Taxon, vol. 52, no. 1, pp. 101-104.

Sessions, A., Burke, E., Presting, G., Aux, G., McElver, J., Patton, D., Dietrich, B., Ho, P., Bacwaden, J., Ko, C., Clarke, J.D., Cotton, D., Bullis, D., Snell, J., Miguel, T., Hutchison, D., Kimmerly, B., Mitzel, T., Katagiri, F., Glazebrook, J., Law, M. \& Goff, S.A. 2002, "A high-throughput Arabidopsis reverse genetics system", The Plant Cell, vol. 14, no. 12, pp. 2985-2994.

Shewry, P.R., Beaudoin, F., Jenkins, J., Griffiths-Jones, S. \& Mills, E.N. 2002, "Plant protein families and their relationships to food allergy", Biochemical Society transactions, vol. 30, no. Pt 6, pp. 906-910.

Shin, D.H., Lee, J.Y., Hwang, K.Y., Kim, K.K. \& Suh, S.W. 1995, "High-resolution crystal structure of the non-specific lipid-transfer protein from maize seedlings", Structure (London, England: 1993), vol. 3, no. 2, pp. 189-199.

Smith, J.E., Tucker, D., Watson, K. \& Jones, G.L. 2007, "Identification of antibacterial constituents from the indigenous Australian medicinal plant Eremophila duttonii F. Muell. (Myoporaceae)", Journal of ethnopharmacology, vol. 112, no. 2, pp. 386-393.

Sodano, P., Caille, A., Sy, D., de Person, G., Marion, D. \& Ptak, M. 1997, "1H NMR and fluorescence studies of the complexation of DMPG by wheat non-specific lipid transfer protein. Global fold of the complex", FEBS letters, vol. 416, no. 2, pp. 130-134.

Sossountzov, L., Ruiz-Avila, L., Vignols, F., Jolliot, A., Arondel, V., Tchang, F., Grosbois, M., Guerbette, F., Miginiac, E. \& Delseny, M. 1991, "Spatial and temporal expression of a maize lipid transfer protein gene", The Plant Cell, vol. 3, no. 9, pp. 923-933.

Sterk, P., Booij, H., Schellekens, G.A., Van Kammen, A. \& De Vries, S.C. 1991, "Cell-specific expression of the carrot EP2 lipid transfer protein gene", The Plant Cell, vol. 3, no. 9, pp. 907921.

Stuart, J.M., Segal, E., Koller, D. \& Kim, S.K. 2003, "A gene-coexpression network for global discovery of conserved genetic modules", Science (New York, N.Y.), vol. 302, no. 5643, pp. 249255.

Sun, G., Dilcher, D.L., Zheng, S. \& Zhou, Z. 1998, "In search of the first flower: A jurassic angiosperm, archaefructus, from northeast china", Science (New York, N.Y.), vol. 282, no. 5394, pp. 1692-1695.

Tassin-Moindrot, S., Caille, A., Douliez, J.P., Marion, D. \& Vovelle, F. 2000, "The wide binding properties of a wheat nonspecific lipid transfer protein. Solution structure of a complex with prostaglandin B2", European journal of biochemistry / FEBS, vol. 267, no. 4, pp. 1117-1124.

Tchang, F., This, P., Stiefel, V., Arondel, V., Morch, M.D., Pages, M., Puigdomenech, P., Grellet, F., Delseny, M. \& Bouillon, P. 1988, "Phospholipid transfer protein: full-length cDNA and amino acid sequence in maize. Amino acid sequence homologies between plant phospholipid transfer proteins", The Journal of biological chemistry, vol. 263, no. 32, pp. 16849-16855. 
Tejera, M.L., Villalba, M., Batanero, E. \& Rodriguez, R. 1999, "Identification, isolation, and characterization of Ole e 7, a new allergen of olive tree pollen", The Journal of allergy and clinical immunology, vol. 104, no. 4 Pt 1, pp. 797-802.

Thoma, S., Hecht, U., Kippers, A., Botella, J., De Vries, S. \& Somerville, C. 1994, "Tissue-specific expression of a gene encoding a cell wall-localized lipid transfer protein from Arabidopsis", Plant Physiology, vol. 105, no. 1, pp. 35-45.

Thoma, S., Kaneko, Y. \& Somerville, C. 1993, "A non-specific lipid transfer protein from Arabidopsis is a cell wall protein", The Plant Journal: for cell and molecular biology, vol. 3, no. 3, pp. 427436.

Tomassen, M.M., Barrett, D.M., van der Valk, H.C. \& Woltering, E.J. 2007, "Isolation and characterization of a tomato non-specific lipid transfer protein involved in polygalacturonasemediated pectin degradation", Journal of experimental botany, vol. 58, no. 5, pp. 1151-1160.

Toriyama, K., Hanaoka, K., Okada, T. \& Watanabe, M. 1998, "Molecular cloning of a cDNA encoding a pollen extracellular protein as a potential source of a pollen allergen in Brassica rapa", FEBS letters, vol. 424, no. 3, pp. 234-238.

Trevino, M.B. \& OConnell, M.A. 1998, "Three drought-responsive members of the nonspecific lipidtransfer protein gene family in Lycopersicon pennellii show different developmental patterns of expression", Plant Physiology, vol. 116, no. 4, pp. 1461-1468.

Tsuboi, S., Osafune, T., Tsugeki, R., Nishimura, M. \& Yamada, M. 1992, "Nonspecific lipid transfer protein in castor bean cotyledon cells: subcellular localization and a possible role in lipid metabolism", Journal of Biochemistry, vol. 111, no. 4, pp. 500-508.

Vignols, F., Wigger, M., Garcia-Garrido, J.M., Grellet, F., Kader, J.C. \& Delseny, M. 1997, "Rice lipid transfer protein (LTP) genes belong to a complex multigene family and are differentially regulated", Gene, vol. 195, no. 2, pp. 177-186.

Wang, K., Senthil-Kumar, M., Ryu, C.M., Kang, L. \& Mysore, K.S. 2012, "Phytosterols play a key role in plant innate immunity against bacterial pathogens by regulating nutrient efflux into the apoplast", Plant Physiology, vol. 158, no. 4, pp. 1789-1802.

Wang, S.Y., Wu, J.H., Ng, T.B., Ye, X.Y. \& Rao, P.F. 2004, "A non-specific lipid transfer protein with antifungal and antibacterial activities from the mung bean", Peptides, vol. 25, no. 8, pp. 12351242.

Wang, Z., Xie, W., Chi, F. \& Li, C. 2005, "Identification of non-specific lipid transfer protein-1 as a calmodulin-binding protein in Arabidopsis", FEBS letters, vol. 579, no. 7, pp. 1683-1687.

Wellman, C.H., Osterloff, P.L. \& Mohiuddin, U. 2003, "Fragments of the earliest land plants", Nature, vol. 425 , no. 6955 , pp. $282-285$.

Weng, H., Molina, I., Shockey, J. \& Browse, J. 2010, "Organ fusion and defective cuticle function in a lacs1 lacs2 double mutant of Arabidopsis", Planta, vol. 231, no. 5, pp. 1089-1100.

Winter, D., Vinegar, B., Nahal, H., Ammar, R., Wilson, G.V. \& Provart, N.J. 2007, "An "Electronic Fluorescent Pictograph" browser for exploring and analyzing large-scale biological data sets", PloS one, vol. 2, no. 8, pp. e718.

Wirtz, K.W. 1991, "Phospholipid transfer proteins", Annual Review of Biochemistry, vol. 60, pp. 73-99.

Wu, G., Robertson, A.J., Liu, X., Zheng, P., Wilen, R.W., Nesbitt, N.T. \& Gusta, L.V. 2004, "A lipid transfer protein gene BG-14 is differentially regulated by abiotic stress, ABA, anisomycin, and sphingosine in bromegrass (Bromus inermis)", Journal of Plant Physiology, vol. 161, no. 4, pp. 449-458.

Xu, C., Fan, J., Cornish, A.J. \& Benning, C. 2008, "Lipid trafficking between the endoplasmic reticulum and the plastid in Arabidopsis requires the extraplastidic TGD4 protein", The Plant Cell, vol. 20, no. 8, pp. 2190-2204. 
Yoon, H.S., Hackett, J.D., Ciniglia, C., Pinto, G. \& Bhattacharya, D. 2004, "A molecular timeline for the origin of photosynthetic eukaryotes", Molecular biology and evolution, vol. 21, no. 5, pp. 809-818.

Yubero-Serrano, E.M., Moyano, E., Medina-Escobar, N., Munoz-Blanco, J. \& Caballero, J.L. 2003, "Identification of a strawberry gene encoding a non-specific lipid transfer protein that responds to ABA, wounding and cold stress", Journal of experimental botany, vol. 54, no. 389, pp. 18651877.

Zachowski, A., Guerbette, F., Grosbois, M., Jolliot-Croquin, A. \& Kader, J.C. 1998, "Characterisation of acyl binding by a plant lipid-transfer protein", European journal of biochemistry / FEBS, vol. 257, no. 2, pp. 443-448.

Zalewski, K., Nitkiewicz, B., Lahuta, L.B., Glowacka, K., Socha, A. \& Amarowicz, R. 2010, "Effect of jasmonic acid-methyl ester on the composition of carbohydrates and germination of yellow lupine (Lupinus luteus L.) seeds", Journal of Plant Physiology, vol. 167, no. 12, pp. 967-973.

Zhang, D., Liang, W., Yin, C., Zong, J., Gu, F. \& Zhang, D. 2010, "OsC6, encoding a lipid transfer protein, is required for postmeiotic anther development in rice", Plant Physiology, vol. 154, no. 1, pp. 149-162.

Zhang, D., Liang, W., Yin, C., Zong, J., Gu, F. \& Zhang, D. 2010, "OsC6, encoding a lipid transfer protein, is required for postmeiotic anther development in rice", Plant Physiology, vol. 154, no. 1, pp. 149-162.

Zimmer, A., Lang, D., Richardt, S., Frank, W., Reski, R. \& Rensing, S.A. 2007, "Dating the early evolution of plants: detection and molecular clock analyses of orthologs", Molecular genetics and genomics : $M G G$, vol. 278, no. 4, pp. 393-402.

Zimmermann, P., Hirsch-Hoffmann, M., Hennig, L. \& Gruissem, W. 2004, "GENEVESTIGATOR. Arabidopsis microarray database and analysis toolbox", Plant Physiology, vol. 136, no. 1, pp. 2621-2632. 
